\title{
MIPAS observations of ozone in the middle atmosphere
}

\author{
Manuel López-Puertas ${ }^{1}$, Maya García-Comas ${ }^{1}$, Bernd Funke ${ }^{1}$, Angela Gardini ${ }^{1}$, Gabriele P. Stiller ${ }^{2}$, \\ Thomas von Clarmann ${ }^{2}$, Norbert Glatthor ${ }^{2}$, Alexandra Laeng ${ }^{2}$, Martin Kaufmann ${ }^{3}$, Viktoria F. Sofieva ${ }^{4}$, \\ Lucien Froidevaux $^{5}$, Kaley A. Walker ${ }^{6}$, and Masato Shiotani ${ }^{7}$ \\ ${ }^{1}$ Instituto de Astrofísica de Andalucía, CSIC, Granada, Spain \\ ${ }^{2}$ Karlsruhe Institute of Technology, Institute of Meteorology and Climate Research, Karlsruhe, Germany \\ ${ }^{3}$ Institute for Energy and Climate Research, Research Centre Jülich, Jülich, Germany \\ ${ }^{4}$ Finnish Meteorological Institute, Earth Observation, Helsinki Finland \\ ${ }^{5}$ Jet Propulsion Laboratory, California Institute of Technology, Pasadena, CA, USA \\ ${ }^{6}$ Department of Physics, University of Toronto, Toronto, Ontario, Canada \\ ${ }^{7}$ Research Institute for Sustainable Humanosphere, Kyoto University, Uji, Kyoto, Japan
}

Correspondence: Manuel López-Puertas (puertas@iaa.es)

Received: 22 December 2017 - Discussion started: 9 January 2018

Revised: 9 March 2018 - Accepted: 18 March 2018 - Published: 18 April 2018

\begin{abstract}
In this paper we describe the stratospheric and mesospheric ozone (version V5r_O3_m22) distributions retrieved from MIPAS observations in the three middle atmosphere modes (MA, NLC, and UA) taken with an unapodized spectral resolution of $0.0625 \mathrm{~cm}^{-1}$ from 2005 until April 2012. $\mathrm{O}_{3}$ is retrieved from microwindows in the 14.8 and $10 \mu \mathrm{m}$ spectral regions and requires non-local thermodynamic equilibrium (non-LTE) modelling of the $\mathrm{O}_{3} v_{1}$ and $v_{3}$ vibrational levels. Ozone is reliably retrieved from $20 \mathrm{~km}$ in the MA mode ( $40 \mathrm{~km}$ for UA and NLC) up to $\sim 105 \mathrm{~km}$ during dark conditions and up to $\sim 95 \mathrm{~km}$ during illuminated conditions. Daytime MIPAS $\mathrm{O}_{3}$ has an average vertical resolution of $3-4 \mathrm{~km}$ below $70 \mathrm{~km}, 6-8 \mathrm{~km}$ at $70-80 \mathrm{~km}, 8-$ $10 \mathrm{~km}$ at $80-90$, and $5-7 \mathrm{~km}$ at the secondary maximum (90$100 \mathrm{~km}$ ). For nighttime conditions, the vertical resolution is similar below $70 \mathrm{~km}$ and better in the upper mesosphere and lower thermosphere: $4-6 \mathrm{~km}$ at $70-100 \mathrm{~km}, 4-5 \mathrm{~km}$ at the secondary maximum, and $6-8 \mathrm{~km}$ at $100-105 \mathrm{~km}$. The noise error for daytime conditions is typically smaller than $2 \%$ below $50 \mathrm{~km}, 2-10 \%$ between 50 and $70 \mathrm{~km}, 10-20 \%$ at 70 $90 \mathrm{~km}$, and $\sim 30 \%$ above $95 \mathrm{~km}$. For nighttime, the noise errors are very similar below around $70 \mathrm{~km}$ but significantly smaller above, being $10-20 \%$ at $75-95 \mathrm{~km}, 20-30 \%$ at $95-$ $100 \mathrm{~km}$, and larger than $30 \%$ above $100 \mathrm{~km}$. The additional major $\mathrm{O}_{3}$ errors are the spectroscopic data uncertainties below $50 \mathrm{~km}(10-12 \%)$ and the non-LTE and temperature errors above $70 \mathrm{~km}$. The validation performed suggests that the
\end{abstract}

spectroscopic errors below $50 \mathrm{~km}$, mainly caused by the $\mathrm{O}_{3}$ air-broadened half-widths of the $v_{2}$ band, are overestimated. The non-LTE error (including the uncertainty of atomic oxygen in nighttime) is relevant only above $\sim 85 \mathrm{~km}$ with values of $15-20 \%$. The temperature error varies from $\sim 3 \%$ up to $80 \mathrm{~km}$ to $15-20 \%$ near $100 \mathrm{~km}$. Between 50 and $70 \mathrm{~km}$, the pointing and spectroscopic errors are the dominant uncertainties. The validation performed in comparisons with SABER, GOMOS, MLS, SMILES, and ACE-FTS shows that MIPAS $\mathrm{O}_{3}$ has an accuracy better than $5 \%$ at and below $50 \mathrm{~km}$, with a positive bias of a few percent. In the $50-75 \mathrm{~km}$ region, MIPAS $\mathrm{O}_{3}$ has a positive bias of $\approx 10 \%$, which is possibly caused in part by $\mathrm{O}_{3}$ spectroscopic errors in the $10 \mu \mathrm{m}$ region. Between 75 and $90 \mathrm{~km}$, MIPAS nighttime $\mathrm{O}_{3}$ is in agreement with other instruments by $10 \%$, but for daytime the agreement is slightly larger, $\sim 10-20 \%$. Above $90 \mathrm{~km}$, MIPAS daytime $\mathrm{O}_{3}$ is in agreement with other instruments by $10 \%$. At night, however, it shows a positive bias increasing from $10 \%$ at $90 \mathrm{~km}$ to $20 \%$ at $95-100 \mathrm{~km}$, the latter of which is attributed to the large atomic oxygen abundance used. We also present MIPAS $\mathrm{O}_{3}$ distributions as function of altitude, latitude, and time, showing the major $\mathrm{O}_{3}$ features in the middle and upper mesosphere. In addition to the rapid diurnal variation due to photochemistry, the data also show apparent signatures of the diurnal migrating tide during both day- and nighttime, as well as the effects of the semi-annual oscillation above $\sim 70 \mathrm{~km}$ in the tropics and mid-latitudes. The tropical 
daytime $\mathrm{O}_{3}$ at $90 \mathrm{~km}$ shows a solar signature in phase with the solar cycle.

\section{Introduction}

Ozone is a key constituent of the atmosphere playing a major role in its energy budget and chemistry, particularly in the stratosphere and upper mesosphere (Brasseur and Solomon, 2005). Typical ozone profiles show two clearly distinguished maxima, one located between 10 and $35 \mathrm{~km}$, the so-called ozone layer, where most ozone resides, and a secondary maximum around the mesopause $(\sim 90-95 \mathrm{~km})$. Ozone has been extensively measured in the stratosphere and also in the mesosphere using different techniques (see e.g. Kaufmann et al. (2003) for measurements taken prior to 2003 and Smith et al. (2013) for the most recent observations, mainly from satellite instruments). Measurements that cover the atmosphere from the lower stratosphere up to the lower thermosphere, both at day- and nighttime conditions and with global latitudinal coverage are, however, not very frequent. MIPAS (Michelson Interferometer for Passive Atmospheric Sounding) is a high-resolution limb sounder on board the Envisat satellite, launched on 1 March 2002 and taking measurements until 8 April 2012, when the Envisat satellite failed. The satellite was inserted into a polar Sun-synchronous orbit at an inclination of $81.5^{\circ}$ and altitude of about $800 \mathrm{~km}$. The orbital period was about $101 \mathrm{~min}$, achieving a global coverage of the Earth with 14.3 daily orbits, with the descending (north-to-south) part crossing the Equator at approximately 10:00 LT (local time) and the ascending part crossing it at approximately 22:00 LT. MIPAS had a wide spectral coverage and a high spectral resolution, operating at $0.025 \mathrm{~cm}^{-1}$ during 2002-2004 and $0.0625 \mathrm{~cm}^{-1}$ from 2005 until 8 April 2012 (Fischer et al., 2008). MIPAS operated with a global latitude coverage (pole-to-pole) and performed measurements during day and night. The instrument spent most of the time observing in the 6-68 km altitude range (the nominal mode, NOM), but it also regularly looked at higher altitudes in its middle atmosphere (MA), noctilucent (NLC), and upper atmosphere (UA) modes (De Laurentis, 2005; Oelhaf, 2008). The retrieval of ozone from the NOM mode has been carried out, among others, by the Institute of Meteorology and Climate Research and Instituto de Astrofísica de Andalucía (IMK/IAA) (Glatthor et al., 2006). In that inversion local thermodynamic equilibrium (LTE) is assumed, which is a good approximation up to about $50 \mathrm{~km}$ and a reasonable approach up to about $60 \mathrm{~km}$ (von Clarmann et al., 2009). MIPAS took a few spectra of the middle atmosphere (only half a day of measurements on 11 June 2003) with its full spectral resolution mode. Ozone concentrations were retrieved from those spectra from the low stratosphere up to the lower thermosphere, including the non-LTE effects (Gil-López et al., 2005). In this paper we focus on the inversion of ozone from the bulk of MIPAS observations of the middle atmosphere taken from 2005 until April 2012 in three different modes (MA, NLC, and UA) with the optimized spectral resolution of $0.0625 \mathrm{~cm}^{-1}$. Part of this dataset (2008-2009), version V4O_O3_m02, was previously retrieved and used in some studies (e.g. Smith et al., 2013). Here we describe the inversion of the entire MA/UA/NLC period, 2005-2012, version V5r_O3_m22, derived from V5 L1b spectra. The method is essentially described in Gil-López et al. (2005). Here we review several aspects of the retrieval baseline including the changes in the non-LTE modelling of $\mathrm{O}_{3}$ and the new microwindows (MWs) used. In addition, an assessment of the quality of the middle atmosphere $\mathrm{O}_{3}$ data, a comparison with the previous version V4O_O3_m02 (sometimes referred to as V4O_502), and a validation with recent middle atmosphere ozone measurements taken by the Sounding of the Atmosphere using Broadband Emission Radiometry (SABER), Global Ozone Monitoring by Occultation of Stars (GOMOS), Microwave Limb Sounder (MLS), Superconducting Submillimeter-Wave Limb-Emission Sounder (SMILES) and Atmospheric Chemistry Experiment's Fourier Transform Spectrometer (ACE-FTS) are also presented. Finally we describe the major features of the $\mathrm{O}_{3}$ database focusing on the mesosphere.

\section{$2 \quad \mathrm{O}_{3}$ non-LTE modelling}

As mentioned below most of the MWs used in the retrieval of $\mathrm{O}_{3}$ in the mesosphere are located in the $9.6 \mu \mathrm{m}$ region, where the $v_{1}$ and $v_{3}$ fundamental, combinational, and hot bands arise. We discuss here the non-LTE modelling of those vibrational levels. The $v_{2}$ fundamental band is used only at the lower altitudes, below $50 \mathrm{~km}$, where it is in LTE (Funke et al., 2012). We should clarify that the non-LTE populations of $\mathrm{O}_{3}$ used in the retrieval have been calculated with the Generic RAdiative traNsfer AnD non-LTE population algorithm (GRANADA) (see Sect. 3). In this section we describe a simplified formulation of non-LTE for $\mathrm{O}_{3}$ with the aim of showing the quantities required for performing the retrieval.

The major processes affecting the populations of the vibrationally excited $\mathrm{O}_{3}\left(v_{1}, v_{2}, v_{3}\right)$ levels are discussed in detail by López-Puertas and Taylor (2001) and are listed in Table 1. The collisional processes (1-4) have been adapted from Table 7 in Funke et al. (2012), to which we have added the simplified radiative processes of (a) the absorption of radiation from the layers below (process 5) and (b) the spontaneous emission (process 6).

From the statistical equilibrium assumption and the processes listed in Table 1, the population of the vibrationally excited $\mathrm{O}_{3}\left(v_{3}\right)$ levels (we focus here on $v_{3}$, from whose emission we are retrieving $\mathrm{O}_{3}$ ) can be obtained, approximately, by

$\frac{\left[\mathrm{O}_{3}\left(v_{3}\right)\right]}{\left[\mathrm{O}_{3}\right]}=\frac{J_{\text {Earth }}+p_{\mathrm{t}}+p_{\mathrm{nt}}}{A+k_{\mathrm{vt}, \mathrm{M}}[\mathrm{M}]+k_{\mathrm{vt}, \mathrm{O}}[\mathrm{O}]+k_{\mathrm{chem}}[\mathrm{O}]}$, 
Table 1. Collisional and radiative processes affecting the $\mathrm{O}_{3}$ vibrational levels.

\begin{tabular}{lll}
\hline No. & Rate & Process \\
\hline 1 & $k_{1}$ & $\mathrm{O}_{2}+\mathrm{O}+\mathrm{M} \rightarrow \mathrm{O}_{3}\left(v_{1}, v_{2}, v_{3}\right)$ \\
2 & $k_{\mathrm{vt}, \mathrm{M}}$ & $\mathrm{O}_{3}\left(v_{1}, v_{2}, v_{3}\right)+\mathrm{M} \rightleftharpoons \mathrm{O}_{3}\left(v_{1}^{\prime}, v_{2}^{\prime}, v_{3}^{\prime}\right)+\mathrm{M}$ \\
3 & $k_{\mathrm{chem}}$ & $\mathrm{O}_{3}\left(v_{1}, v_{2}, v_{3}\right)+\mathrm{O} \rightarrow \mathrm{O}_{2}+\mathrm{O}_{2}$ \\
4 & $k_{\mathrm{vt}, \mathrm{O}}$ & $\mathrm{O}_{3}\left(v_{1}, v_{2}, v_{3}\right)+\mathrm{O} \rightarrow \mathrm{O}_{3}\left(v_{1}^{\prime}, v_{2}^{\prime}, v_{3}^{\prime}\right)+\mathrm{O}$ \\
5 & $J_{\text {Earth }}$ & $\mathrm{O}_{3}+\mathrm{h} v \rightarrow \mathrm{O}_{3}\left(v_{1}, v_{2}, v_{3}\right)$ \\
6 & $A$ & $\mathrm{O}_{3}\left(v_{1}, v_{2}, v_{3}\right) \rightarrow \mathrm{O}_{3}\left(v_{1}^{\prime}, v_{2}^{\prime}, v_{3}^{\prime}\right)+\mathrm{h} v$ \\
\hline
\end{tabular}

Note that the energy of the $\mathrm{O}_{3}\left(v_{1}, v_{2}, v_{3}\right)$ level is larger than that of $\mathrm{O}_{3}\left(v_{1}^{\prime}, v_{2}^{\prime}, v_{3}^{\prime}\right)$.

where the brackets denote concentrations, $J_{\text {Earth }}$ is the excitation rate of $\mathrm{O}_{3}\left(v_{3}\right)$ due to the absorption of $v_{3}$ photons coming from the lower atmospheric regions (upwelling flux), $A$ is the Einstein coefficient of the $v_{3}=1$ band, [O] the atomic oxygen concentration, $[\mathrm{M}]$ the air molecules concentration (sum of $\mathrm{N}_{2}$ and $\mathrm{O}_{2}$ ), and the other collisional rates are defined in Table 1. $p_{\mathrm{t}}$ is the specific thermal production of $\mathrm{O}_{3}\left(v_{3}\right)$ given by

$p_{\mathrm{t}}=k_{\mathrm{vt}, \mathrm{M}}[\mathrm{M}] \exp \left[-E\left(v_{3}\right) / k T\right]$,

where $T$ is the kinetic temperature, $k$ the Boltzmann constant and $E\left(v_{3}\right)$ the energy of the $\mathrm{O}_{3}\left(v_{3}\right)$ level. The specific production due to non-thermal processes (chemiluminescence, process 1 in Table 1 ), $p_{\mathrm{nt}}$, is given by

$p_{\mathrm{nt}}=k_{1}\left[\mathrm{O}_{2}\right][\mathrm{M}]\left([\mathrm{O}] /\left[\mathrm{O}_{3}\right]\right) \phi\left(v_{3}\right)$,

where $\phi\left(v_{3}\right)$ is the fraction of the $\mathrm{O}_{3}$ molecules produced by process 1 , which finally end excited in the $\mathrm{O}_{3}\left(v_{3}\right)$ level. In practice, $\phi\left(v_{3}\right)$ depends not only on the nascent distribution of reaction 1 but also, and mainly for the lower $v_{3}$ levels, on the radiative and collisional relaxations of the more energetic $\left(v_{1}, v_{2}, v_{3}\right)$ levels, i.e. on $A, k_{\mathrm{vt}, \mathrm{M}}, k_{\mathrm{vt}, \mathrm{O}}$, and $k_{\mathrm{chem}}$ for those levels and also on [M] and [O]. From all those parameters, the only unknown in our case is the atomic oxygen concentration, [O].

For the retrieval of $\mathrm{O}_{3}$, one needs the $\left[\mathrm{O}_{3}\left(v_{3}\right)\right] /\left[\mathrm{O}_{3}\right]$ ratio of Eq. (1), which is proportional to the $\mathrm{O}_{3}\left(v_{3}\right)$ vibrational temperature and hence to the measured $\mathrm{O}_{3}$ emission, to be the least dependent as possible on kinetic rates and other atmospheric parameters. For the MIPAS $\mathrm{O}_{3}$ retrieval, all the parameters in Eqs. 1, 2, and 3 are known, or measured simultaneously by MIPAS, except [O].

Because of the rapid timescales for ozone production and loss in the non-LTE region, the assumption of photochemical equilibrium above around $60 \mathrm{~km}$ is valid. Thus, from the major photochemical reactions affecting $\mathrm{O}_{3}$ in the mesosphere and lower thermosphere (see Table 2), the non-thermal production, $p_{\mathrm{nt}}$, and [O] are given for daytime conditions, respectively, by
Table 2. Major photochemical reactions affecting $\mathrm{O}_{3}$ in the mesosphere and lower thermosphere.

\begin{tabular}{lll}
\hline No. & Rate & Process \\
\hline 1 & $k_{1}$ & $\mathrm{O}_{2}+\mathrm{O}+\mathrm{M} \rightarrow \mathrm{O}_{3}\left(v_{1}, v_{2}, v_{3}\right)$ \\
2 & $k_{2}$ & $\mathrm{H}+\mathrm{O}_{3} \rightarrow \mathrm{OH}^{*}(\mathrm{v})+\mathrm{O}_{2}$ \\
3 & $k_{3}$ & $\mathrm{O}+\mathrm{O}_{3} \rightarrow \mathrm{O}_{2}+\mathrm{O}_{2}$ \\
4 & $J_{\text {Sun }}$ & $\mathrm{O}_{3}+\mathrm{h} v \rightarrow \mathrm{O}_{2}+\mathrm{O}$ \\
\hline
\end{tabular}

$p_{\text {nt, day }}=J_{\text {Sun }} \phi\left(v_{3}\right)$ and

$[\mathrm{O}]_{\mathrm{day}} \approx \frac{J_{\mathrm{Sun}}\left[\mathrm{O}_{3}\right]}{k_{1}\left[\mathrm{O}_{2}\right][\mathrm{M}]}$,

where the chemical losses $\left(k_{2}\right.$ and $\left.k_{3}\right)$ have been neglected. In this way, we have no major limitation of unknown atmospheric parameters in the $\mathrm{O}_{3}$ non-LTE retrieval during daytime if we update the non-LTE model with the $\mathrm{O}_{3}$ abundance in each iteration.

During nighttime, assuming also photochemical equilibrium and the processes in Table 2, the non-thermal production and [O] are given, respectively, by

$p_{\mathrm{nt}, \mathrm{night}}=\frac{k_{2}[\mathrm{H}]}{1-\frac{k_{3}\left[\mathrm{O}_{3}\right]}{k_{1}\left[\mathrm{O}_{2}\right][\mathrm{M}]}}$ and
$[\mathrm{O}]_{\text {night }} \approx \frac{k_{2}[\mathrm{H}]\left[\mathrm{O}_{3}\right]}{k_{1}\left[\mathrm{O}_{2}\right][\mathrm{M}]-k_{3}\left[\mathrm{O}_{3}\right]}$.

In this case, even iterating, we still have the unknown of the atomic hydrogen concentration, $[\mathrm{H}]$, which has to be taken from models or from parameterization. As we see, the nonthermal production in nighttime is directly proportional to $[\mathrm{H}]$. Then, in order to estimate the errors introduced by the uncertainty in $[\mathrm{H}]$, it is worthwhile to estimate the importance of the contribution of the non-thermal term, $p_{\text {nt, night }}$ in Eq. (6), in comparison with the radiative and thermal contributions, $J_{\text {Earth }}$ and $p_{\mathrm{t}}$ in Eq. (1). Figure 1 show the calculations of these terms computed with the GRANADA model for a few nighttime profiles for 2 days typical of equinox and solstice. The figure shows that the contribution of the nonthermal term to the excitation of $\mathrm{O}_{3}\left(v_{3}=1\right)$ is, in the worst case, a factor of 5 smaller than the radiative and thermal excitations. We then expect that the uncertainties in the inputted $[\mathrm{H}]$ from the US Naval Research Laboratory Mass Spectrometer and Incoherent Scatter Radar model (NRLMSISE-00) (Picone et al., 2002, see below) would not introduce large uncertainties in the retrieved $\mathrm{O}_{3}$. This effect, however, is larger for higher $\mathrm{O}_{3}$ vibrational levels because for these states the radiative term is negligible and the non-thermal part is larger. Thus the uncertainty in $[\mathrm{H}]$ might introduce a larger error for the case of wide band radiometers measuring a significant contribution of the hot bands' emission. 


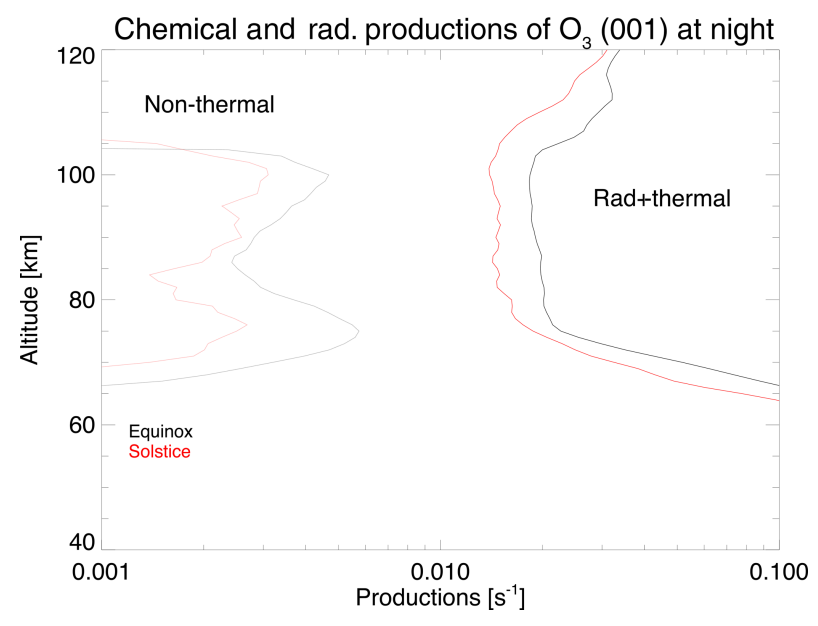

Figure 1. Specific production terms of the population of $\mathrm{O}_{3}(001)$ in nighttime for 2 days typical of equinox (black) and solstice (red). Dotted lines are the specific non-thermal productions of $\mathrm{O}_{3}\left(v_{3}=1\right)$ (Eq. 6), and solid lines are the sum of the radiative absorption and thermal collisions, $J_{\text {Earth }}$ and $p_{\mathrm{t}}$ in Eq. (1).

\section{Ozone non-LTE retrieval}

As described above, we used MIPAS spectra taken in the MA, NLC, and UA modes. In the MA mode, the spectra are taken at limb tangent heights from about 20 up to $102 \mathrm{~km}$ with a vertical spacing of $3 \mathrm{~km}$. The UA mode ranges from about 42 up to $172 \mathrm{~km}$, which has a $3 \mathrm{~km}$ vertical sampling up to 102 and $5 \mathrm{~km}$ above. The NLC mode is a variant of the MA mode specifically tailored for measuring the NLCs during the summers (De Laurentis, 2005; Oelhaf, 2008). In this mode the spectra are taken at tangent heights from 39 up to $78 \mathrm{~km}$ at $3 \mathrm{~km}$ steps, from 78 up to $87 \mathrm{~km}$ at $1.5 \mathrm{~km}$ steps, and from 87 up to $102 \mathrm{~km}$ again in $3 \mathrm{~km}$ steps. MIPAS horizontal field of view (FOV) is approximately $30 \mathrm{~km}$.

The method used for the inversion of ozone under nonLTE conditions is essentially described in Gil-López et al. (2005). In that work the retrieval was adapted for the very few (only 26 orbits) MIPAS data of the upper atmosphere taken on June 2003 at the full spectral resolution of $0.025 \mathrm{~cm}^{-1}$. Here we briefly summarize the approach, discuss the new MWs used in the inversion of the MA, NLC, and UA observational modes (taken at $0.0625 \mathrm{~cm}^{-1}$ ), and review the changes in the non-LTE modelling of $\mathrm{O}_{3}$ vibrational levels.

The MIPAS V5r_O3_m22 ozone retrieval is based on a constrained multilinear least-squares fitting of non-LTE limb radiances. That is performed using the IMK/IAA Scientific Processor (von Clarmann et al., 2003, 2009) extended with the non-LTE GRANADA algorithm (Funke et al., 2012), which is able to cope with non-LTE emissions. Funke et al. (2001) describe the peculiarities of the retrievals under consideration of non-LTE. The basic retrieval equations, the methods for characterization of results through error estimates and vertical and horizontal averaging kernels, the iteration and convergence criteria, and the regularization method are described in von Clarmann et al. $(2003,2009)$. Version V5 (5.02/5.06) of the ESA-calibrated L1b spectra was used (see Raspollini et al., 2010, and references therein).

The inversion is performed after a retrieval of the residual spectral shift and the non-LTE retrieval of temperature (García-Comas et al., 2012, 2014). The IMK/IAA processor simultaneously retrieves, besides the $\mathrm{O}_{3}$ abundance, microwindow- and altitude-dependent continuum radiation and zero level calibration corrections (the latter, assumed constant with altitude).

The retrievals are performed from the surface to $120 \mathrm{~km}$ over a fixed altitude grid of $1 \mathrm{up}$ to $50 \mathrm{~km}$, at $72-75 \mathrm{~km}$, and at $77-88 \mathrm{~km}$; of $2 \mathrm{~km}$ at $50-72 \mathrm{~km}, 75-77 \mathrm{~km}$, and $88-102 \mathrm{~km}$; and of $5 \mathrm{~km}$ from 105 up to $120 \mathrm{~km}$. The grids have been selected as a trade-off between higher accuracy and computational efficiency. The forward calculations are performed using the same grid. The oversampled retrieval grid, finer than the MIPAS vertical sampling of $3 \mathrm{~km}$, makes necessary the use of a regularization in order to obtain stable solutions. We used here a Tikhonov-type first-order smoothing constraint (Tikhonov, 1963). The numerical integration of the signal over the $3 \mathrm{~km}$ FOV is done using five pencil beams. The selected width of the integration window (apodized instrument line shape (ILS) function) avoids channel border effects. Forward model calculations along the line of sight (LOS) are done considering horizontal gradient corrections. Thus, they account for changes in the populations (either in LTE or in non-LTE) of the emitting $\mathrm{O}_{3}$ levels along the LOS due to kinetic temperature variations.

Ozone is reliably retrieved from $20 \mathrm{~km}$ in the MA mode (40 km for the UA and NLC modes) up to $\sim 105 \mathrm{~km}$ during dark conditions and up to $\sim 95 \mathrm{~km}$ during illuminated conditions. The logarithm of the volume mixing ratio (VMR) is retrieved from MWs covering rotational-vibrational emissions of the $\mathrm{O}_{3}$ main isotope. They have been selected from a broad spectral region, covered by channel A $\left(685-970 \mathrm{~cm}^{-1}\right)$ and channel AB (1020-1170 $\left.\mathrm{cm}^{-1}\right)$, and they vary with tangent altitudes in order to optimize computation time and minimize systematic errors (von Clarmann and Echle, 1998). The MWs used are listed in Table 3, and Fig. 2 shows some examples of single MIPAS spectra in the A and AB channels. The MWs are an extension of the set used for the ozone retrieved from the MIPAS NOM mode of observation, covering altitudes below $70 \mathrm{~km}$ (von Clarmann et al., 2009). Below $50 \mathrm{~km}$, we use the same MWs as in the NOM retrieval, located all in channel A. Above $50 \mathrm{~km}$, the MWs used are mainly located in channel $\mathrm{AB}$ and are strongly affected by non-LTE.

The MIPAS V5r_O3_m22 ozone retrieval setup uses the following inputs. The $\mathrm{O}_{3}$ a priori is taken from a MIPAS dedicated climatology (similar to that described in Funke et al., 2012). Pressure, LOS, temperature, and temperature horizontal gradients are taken from MIPAS T-LOS retrieval V5r_T_m21 (García-Comas et al., 2014). They have been retrieved from the $\mathrm{CO}_{2}$ emission near $15 \mu \mathrm{m}$ and recorded 
Table 3. Microwindows and altitude ranges used in the retrieval of MIPAS ozone V5r_O3_m22.

\begin{tabular}{|c|c|c|c|c|c|c|c|c|c|c|c|c|c|c|c|c|c|c|c|c|c|c|c|}
\hline \multirow[t]{2}{*}{ No. } & \multicolumn{2}{|c|}{ Wave number $\left(\mathrm{cm}^{-1}\right)$} & \multicolumn{21}{|c|}{ Altitudes (km) } \\
\hline & Minimum & Maximum & 18 & 21 & 24 & 27 & 30 & 33 & 36 & 39 & 42 & 45 & 48 & 51 & 54 & 57 & 60 & 63 & 66 & 69 & 72 & 75 & $78-102$ \\
\hline 1 & 687.6875 & 688.6875 & & & & & & $\mathbf{\square}$ & & $\mathbf{\square}$ & घ & 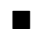 & & & $\mathbf{\square}$ & $\mathbf{\square}$ & $\mathbf{\square}$ & & $\mathbf{\square}$ & [ & $\square$ & $\mathbf{\square}$ & \\
\hline 2 & 689.3125 & 691.8750 & & & 口 & 口 & 口 & & & 口 & घ & घ & ש & घ & ש & ש & घ & $=$ & घ & घ & ש & घ & \\
\hline 3 & 692.2500 & 695.1875 & & & & & & & ש & $\mathbf{\square}$ & च & $\mathbf{\square}$ & ש & ש & [ & 口 & घ & $\boldsymbol{\square}$ & 口 & [ & 口 & $\mathbf{\square}$ & \\
\hline 4 & 707.1250 & 710.0625 & & & & ש & $\mathbf{\square}$ & 口 & घ & $\mathbf{\square}$ & [ & $\mathbf{\square}$ & ש & $\boldsymbol{\square}$ & $\mathbf{\square}$ & 口 & ש & $\boldsymbol{\square}$ & 口 & ש & घ & $\mathbf{\square}$ & \\
\hline 5 & 712.3125 & 713.4375 & & & & & & & & $\mathbf{\square}$ & घ & $\mathbf{\square}$ & $\mathbf{\square}$ & & $\mathbf{\square}$ & & & & & & & & \\
\hline 6 & 713.5000 & 716.4375 & & & 口 & 口 & 口 & $\mathbf{\square}$ & $\mathbf{\square}$ & $\mathbf{\square}$ & घ & $\mathbf{\square}$ & $\mathbf{\square}$ & $\mathbf{\square}$ & & $\mathbf{\square}$ & $\boldsymbol{\square}$ & $\mathbf{\square}$ & $\mathbf{\square}$ & घ & $\mathbf{\square}$ & घ & \\
\hline 7 & 716.5000 & 719.4375 & & & - & 口 & & ש & 口 & 口 & ש & घ & ש & 口 & ש & 口 & घ & ש & 口 & ש & 口 & घ & \\
\hline 8 & 720.7500 & 723.6875 & & & & 口 & $\mathbf{\square}$ & च & च & $\mathbf{\square}$ & च & $\mathbf{\square}$ & n & 口 & 口 & 口 & 口 & n & 口 & ש & 口 & $\mathbf{\square}$ & \\
\hline 9 & 728.5000 & 729.3750 & & & & & & च & घ & $\mathbf{\square}$ & च & $\mathbf{\square}$ & n & 口 & 口 & 口 & घ & 口 & 口 & च & 口 & $\mathbf{\square}$ & \\
\hline 10 & 730.0625 & 730.5000 & & & & & & $\mathbf{\square}$ & $\mathbf{\square}$ & $\mathbf{\square}$ & a & $\mathbf{\square}$ & $\mathbf{\square}$ & $\mathbf{\square}$ & $\mathbf{\square}$ & $\mathbf{\square}$ & $\mathbf{\square}$ & $\mathbf{\square}$ & $\mathbf{\square}$ & घ & $\mathbf{\square}$ & $\mathbf{\square}$ & \\
\hline 11 & 731.9375 & 732.8750 & & & 口 & ש & 口 & & & $\mathbf{\square}$ & & & & [ & $\mathbf{\square}$ & 口 & 口 & $\boldsymbol{\square}$ & 口 & & ש & $\mathbf{\square}$ & \\
\hline 12 & 734.0000 & 734.7500 & & & & & & घ & घ & & घ & घ & a & a & E & & & & & घ & च & a & \\
\hline 13 & 736.4375 & 739.3750 & घ & a & & 口 & & a & a & $\mathbf{a}$ & a & a & a & a & a & च & 口 & [ & a & a & च & a & \\
\hline 14 & 739.4375 & 741.9375 & & & & & $\mathbf{a}$ & a & 口 & $\mathbf{\square}$ & a & $\mathbf{a}$ & $\pi$ & 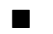 & 口 & 口 & a & & $\mathbf{a}$ & $=$ & 口 & $\mathbf{a}$ & \\
\hline 15 & 745.2500 & 745.6875 & a & & & & & घ & 口 & [ & a & a & 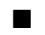 & n & $\mathbf{a}$ & घ & 口 & & $\mathbf{\square}$ & घ & घ & a & \\
\hline 16 & 746.6875 & 747.1250 & & 口 & 口 & 口 & $\mathbf{\square}$ & च & घ & $\mathbf{\square}$ & 口 & $\mathbf{\square}$ & 口 & घ & 口 & 口 & 口 & & 口 & ש & 口 & $\mathbf{\square}$ & \\
\hline 17 & 747.6250 & 748.3750 & & & & 口 & $\mathbf{\square}$ & घ & घ & & च & $\mathbf{\square}$ & 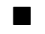 & [ & 口 & & & & 口 & च & 口 & $\mathbf{\square}$ & \\
\hline 18 & 749.5625 & 752.5000 & & a & 口 & ש & 口 & ש & a & $\mathbf{\square}$ & $\mathbf{\square}$ & $\mathbf{\square}$ & $\mathbf{\square}$ & $\mathbf{\square}$ & $\mathbf{\square}$ & $\mathbf{\square}$ & $\mathbf{\square}$ & - & $\mathbf{\square}$ & घ & $\mathbf{\square}$ & घ & \\
\hline 19 & 752.9375 & 755.8750 & च & 口 & 口 & & & ש & 口 & $\mathbf{\square}$ & च & $\mathbf{\square}$ & [ & $\mathbf{\square}$ & $\mathbf{\square}$ & घ & 口 & 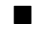 & 口 & ש & 口 & $\mathbf{\square}$ & \\
\hline 20 & 758.3750 & 759.4375 & च & 口 & $\mathbf{\square}$ & 口 & $\mathbf{\square}$ & 口 & 口 & $\mathbf{\square}$ & 口 & $\mathbf{\square}$ & 口 & $\mathbf{\square}$ & $\mathbf{\square}$ & 口 & 口 & 口 & 口 & [ & 口 & $\mathbf{\square}$ & \\
\hline 21 & 759.5000 & 761.8750 & & & $\mathbf{\square}$ & & & $\mathbf{\square}$ & 口 & $\mathbf{\square}$ & घ & $\mathbf{\square}$ & $\mathbf{\square}$ & $\mathbf{\square}$ & $\mathbf{\square}$ & $\mathbf{\square}$ & घ & $\mathbf{\square}$ & $\mathbf{\square}$ & घ & $\mathbf{\square}$ & $\mathbf{\square}$ & \\
\hline 22 & 765.0000 & 765.6250 & & & & & & & 口 & $\mathbf{\square}$ & a & $\mathbf{\square}$ & $\mathbf{\square}$ & $\mathbf{\square}$ & $\mathbf{\square}$ & $\boldsymbol{\square}$ & घ & $\boldsymbol{\square}$ & $\mathbf{\square}$ & a & $\mathbf{\square}$ & $\mathbf{\square}$ & \\
\hline 23 & 767.5000 & 768.0000 & घ & 口 & $\mathbf{\square}$ & घ & $\mathbf{\square}$ & घ & घ & $\mathbf{\square}$ & घ & $\mathbf{\square}$ & $\mathbf{\square}$ & $\mathbf{\square}$ & $\mathbf{\square}$ & घ & घ & a & $\mathbf{a}$ & घ & घ & $\mathbf{\square}$ & \\
\hline 24 & 771.8750 & 772.1250 & ש & 口 & 口 & 口 & 口 & घ & 口 & 口 & ש & च & & & 口 & 口 & घ & घ & 口 & ש & घ & घ & \\
\hline 25 & 774.2500 & 774.5625 & & 口 & $\mathbf{\square}$ & घ & & & 口 & $\mathbf{\square}$ & घ & $\mathbf{\square}$ & & & 口 & & & & 口 & घ & & & \\
\hline 26 & 776.5000 & 776.7500 & & & & & & & & & n & $\mathbf{\square}$ & & $\mathbf{u}$ & & $\boldsymbol{\square}$ & $\mathbf{\square}$ & a & $\mathbf{\square}$ & a & & & \\
\hline 27 & 780.2500 & 781.9375 & च & & & & & $\boldsymbol{\square}$ & 口 & a & $\mathbf{\square}$ & $\mathbf{\square}$ & 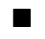 & 口 & $\mathbf{\square}$ & $\boldsymbol{\square}$ & घ & $\boldsymbol{\square}$ & $\mathbf{\square}$ & a & $\boldsymbol{\square}$ & $\mathbf{\square}$ & \\
\hline 28 & 788.9375 & 789.6875 & च & & & & & 口 & 口 & $\mathbf{D}$ & 口 & $\mathbf{\square}$ & D & $\mathbf{\square}$ & $\mathbf{\square}$ & 口 & 口 & 口 & 口 & [ & 口 & $\mathbf{\square}$ & \\
\hline 29 & 790.7500 & 791.0000 & घ & & & & & & & & & & $\mathbf{\square}$ & & & & & & & & & & \\
\hline 30 & 791.1875 & 791.5625 & a & 口 & & & & & 口 & $\mathbf{\square}$ & a & $\mathbf{0}$ & a & $\mathbf{\square}$ & $\mathbf{\square}$ & $\mathbf{\square}$ & a & a & 口 & a & घ & $\mathbf{a}$ & \\
\hline 31 & 1034.1250 & 1034.3750 & & & & & & & & & & & & & & & & & $\mathbf{\square}$ & घ & 口 & $\mathbf{\square}$ & $\mathbf{\square}$ \\
\hline 32 & 1034.4375 & 1035.0000 & & & & & & & & & & & & $\mathbf{\square}$ & $\mathbf{\square}$ & घ & 口 & $\mathbf{\square}$ & $\mathbf{\square}$ & घ & $\mathbf{\square}$ & $\mathbf{\square}$ & $\mathbf{\square}$ \\
\hline 33 & 1038.1875 & 1039.0000 & & & & & & & & & & & & $\mathbf{\square}$ & $\mathbf{\square}$ & घ & 口 & 口 & $\mathbf{\square}$ & घ & 口 & $\mathbf{\square}$ & $\mathbf{\square}$ \\
\hline 34 & 1040.0000 & 1040.8125 & & & & & & & & & & & & $\mathbf{\square}$ & $\mathbf{\square}$ & $\boldsymbol{\square}$ & घ & $\boldsymbol{\square}$ & $\mathbf{\square}$ & घ & $\boldsymbol{\square}$ & $\mathbf{\square}$ & $\mathbf{\square}$ \\
\hline 35 & 1048.8125 & 1049.5000 & & & & & & & & & & & & & & & & 口 & 口 & [ & 口 & $\mathbf{\square}$ & 口 \\
\hline 36 & 1050.6250 & 1051.8125 & & & & & & & & & & & & & & & & 口 & 口 & [ & 口 & $\mathbf{\square}$ & 口 \\
\hline 37 & 1053.3125 & 1053.8125 & & & & & & & & & & & & & & & & 口 & 口 & 口 & 口 & $\mathbf{\square}$ & 口 \\
\hline 38 & 1054.6875 & 1055.5000 & & & & & & & & & & & & & & & & & D & घ & घ & $\mathbf{\square}$ & 口 \\
\hline
\end{tabular}

in channel A, accounting for the non-LTE effects. The detailed description of the method and the characterization of the inverted pressure-temperature profiles are described in García-Comas et al. (2012). The upgrades in the retrieval of the temperature used here (V5r_T_m21) and a validation of the results are reported by García-Comas et al. (2014). This version of MIPAS temperatures correct the main systematic errors of the previous version and have, in general, a remarkable agreement with the measurements taken by ACE-FTS, MLS, OSIRIS, SABER, SOFIE, and the Rayleigh lidars at Mauna Loa and Table Mountain. In the region of interest here, however, there are still significant differences, with the MIPAS mesopause differing by $5-10 \mathrm{~K}$ from the other instruments, being warmer than SABER, MLS, and OSIRIS and colder than ACE-FTS and SOFIE.

The $\mathrm{O}_{3}$ spectroscopic data were taken from the HITRAN 2008 database (Rothman et al., 2009). A test performed using the HITRAN $2016 \mathrm{O}_{3}$ database (Gordon et al., 2017) has shown that the radiances are just marginally larger (only $0.5 \%$ in channel $\mathrm{A}$ and $0.25 \%$ in channel $\mathrm{AB}$ ).

The $\mathrm{O}_{3}$ non-LTE vibrational populations were computed online in each iteration of the inversion by using the GRANADA model (Funke et al., 2012). As described above, the $\mathrm{O}_{3}$ non-LTE model requires several inputs. The set of $\mathrm{O}_{3}$ vibrational levels, the non-LTE collisional scheme and the rate constants are based on the GRANADA model except as noted below.

The exponent $a$ in the rate $k_{1}=6.0 \times 10^{-34}(T / 300)^{a}$ of reaction $\mathrm{O}+\mathrm{O}_{2}+\mathrm{M} \rightarrow \mathrm{O}_{3}\left(v_{1}, v_{2}, v_{3}\right)+\mathrm{M}$ has been updated from 2.3 to 2.4 following Burkholder et al. (2015). This has a small effect on the $\mathrm{O}_{3} v_{1}$ and $v_{3}$ vibrational temperatures and also on the retrieved $\mathrm{O}_{3}$.

The collisional deactivation of $\mathrm{O}_{3}\left(v_{1}, v_{2}, v_{3}\right)$ (process 2 in Table 1) with $\Delta v_{1}$ or $\Delta v_{3}=-1$ and $\Delta v_{2}=1$ (process 2 c, $k_{d}$, in Table 7 of Funke et al., 2012) was erroneously implemented in the previous version with a rate of 

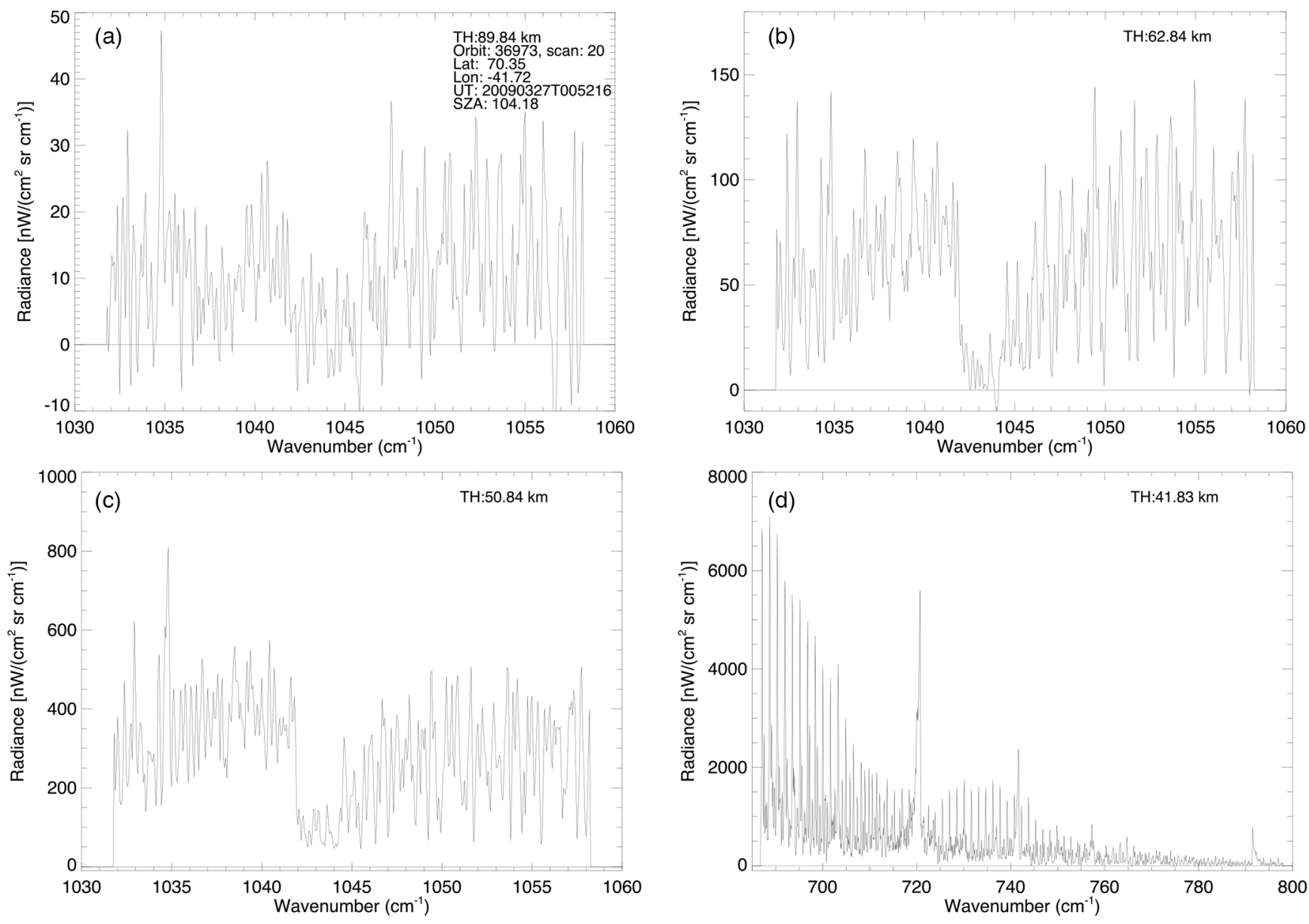

Figure 2. Examples of MIPAS L1b apodized single spectra in channel A (d) and in channel AB (a-c) at several tangent heights (as labelled) used in the inversion of $\mathrm{O}_{3}$. The geolocation of the spectra is given in panel (a). The radiance in the $1030-1060 \mathrm{~cm}^{1}$ spectral region is dominated by $\mathrm{O}_{3}$ features. However, in channel A (d), it is dominated by $\mathrm{CO}_{2}$ emissions and the $\mathrm{O}_{3}$ contribution is hardly noticed.

$3.1 \times 10^{-15}(T / 300)^{1 / 2}$. Now we include the expression in Table 7 of Funke et al. (2012) but limited to a minimum value of $4 \times 10^{-16} \mathrm{~cm}^{3} \mathrm{~s}^{-1}$ at temperatures below $200 \mathrm{~K}$ (Menard et al., 1992). Although this change in the rate coefficient is rather large, its impact on the $\mathrm{O}_{3}\left(v_{3}\right)$ vibrational temperature is very small, as it is dominated by the relaxation to $v_{2}$. This leads to an $\mathrm{O}_{3}$ VMR about $5 \%$ smaller between 70 and $85 \mathrm{~km}$.

The chemical quenching of vibrationally excited $\mathrm{O}_{3}$ by $\mathrm{O}$, $\mathrm{O}_{3}\left(v_{1}, v_{2}, v_{3}\right)+\mathrm{O} \rightarrow \mathrm{O}_{2}+\mathrm{O}_{2}$, has been neglected in this version. This implies larger $\mathrm{O}_{3}\left(v_{3}\right)$ vibrational temperatures and hence smaller retrieved $\mathrm{O}_{3}$ abundances. Note, however, that the total quenching of $\mathrm{O}_{3}\left(v_{1}, v_{3}\right)$ by $\mathrm{O}$, including also collisional relaxation by $\mathrm{O}$ (process 4) in Table 1), is still within the measurement errors of the deactivation of $\mathrm{O}_{3}\left(v_{1}, v_{3}\right)$ (West et al., 1976, 1978, see discussion below).

As shown in Sect. 2, the inversion of $\mathrm{O}_{3}$ under non-LTE conditions requires knowledge of the atomic oxygen concentration, [O]. In our retrievals, we constrain the $\mathrm{O}$ abundance by employing photochemical equilibrium with the $\mathrm{O}_{3}$ abun- dance retrieved in the previous iteration. This photochemical constraint for $[\mathrm{O}] /\left[\mathrm{O}_{3}\right]$ is an optional feature in GRANADA which has been switched on in this retrieval below $97 \mathrm{~km}$.

At night, the non-thermal production and $\mathrm{O}$ depends not only on $\mathrm{O}_{3}$ but also on hydrogen, $\mathrm{H}$ (see Eqs. 6 and 7). For this reason, we use the $\mathrm{H}$ abundance from the NRLMSISE00 model (Picone et al., 2002) in the photochemical equilibrium computation. Above $97 \mathrm{~km}$ we use the atomic oxygen from the Whole Atmosphere Community Climate Model with specified dynamics (SD-WACCM) simulations spanning over the time period of the measurements (Garcia et al., 2014). To be more precise, both profiles were merged in the 92-102 km region using a hyperbolic tangent function centred at $97 \mathrm{~km}$. SD-WACCM (in the following just WACCM) is constrained with output from NASA's Modern-Era Retrospective Analysis (MERRA) (Rienecker et al., 2011) below approximately $1 \mathrm{hPa}$. The main reason for including WACCM about that altitude is motivated by the lack of or incorrect latitudinal and seasonal variation of atomic oxygen in the NRLMSISE-00 model. 

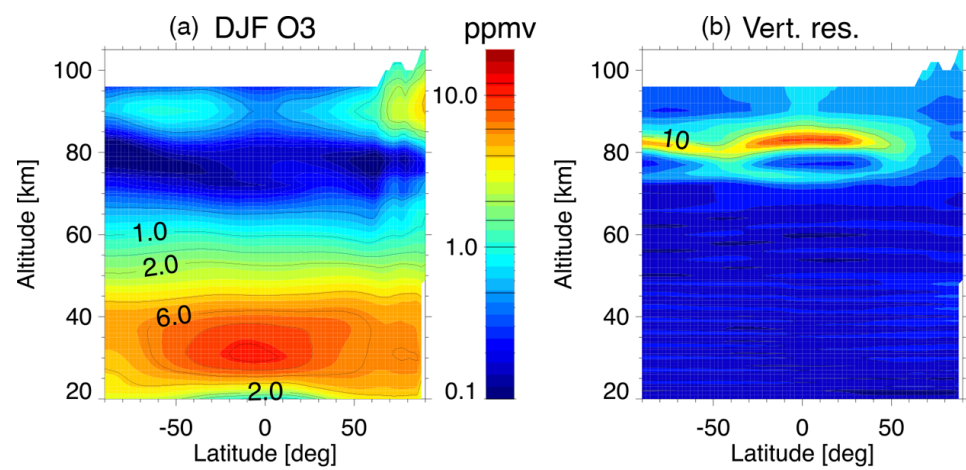

(d) MAM O3
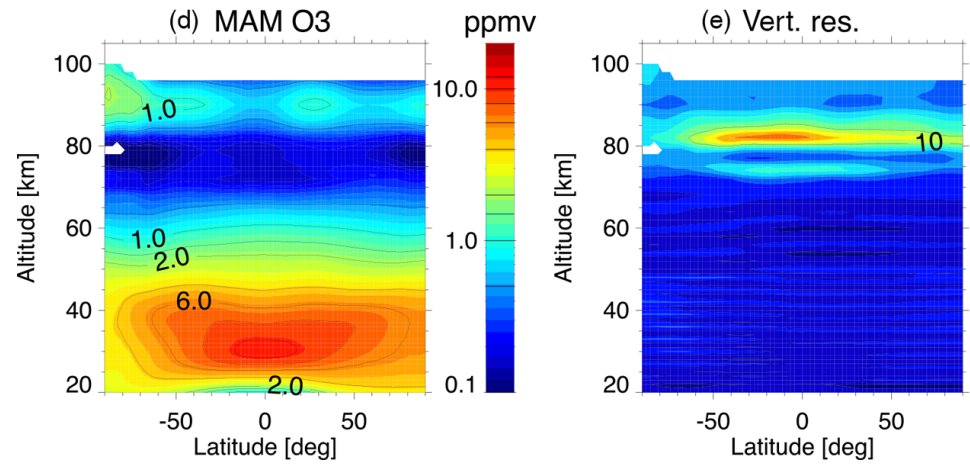
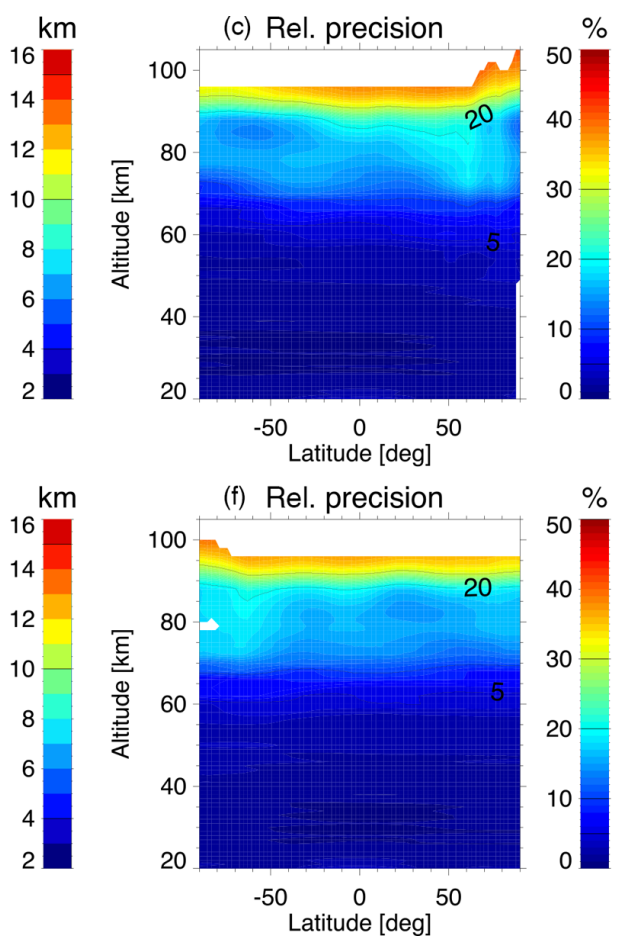

Figure 3. Latitude-altitude cross sections of MIPAS MA daytime ozone (a, d), its vertical resolution (b, e), and single profile noise error (1 $\sigma$, c, f) for solstice (December-January-February: DJF) (a-c) and equinox (March-April-May; MAM) (d-f). All measurements from 2005 to 2012 are included. White areas denote regions where the retrieved $\mathrm{O}_{3}$ is not significant. Contour lines are marked in the colour bar scale.

The forward model also includes the contribution (as a potential overlap with $\mathrm{O}_{3}$ lines) of $\mathrm{CO}_{2}$ lines. As for $\mathrm{O}_{3}$, we also include the emissions by $\mathrm{CO}_{2}$ bands in non-LTE. A detailed description of the $\mathrm{CO}_{2}$ non-LTE model used and all the required input parameters can be found in Jurado-Navarro et al. (2016).

\section{Characterization of the retrieved $\mathrm{O}_{3}$ and error analysis}

Figures 3 and 4 show seasonal zonal means of $\mathrm{O}_{3}$ retrieved from MIPAS and the mean of the noise error $(1 \sigma)$ and vertical resolution for the MA mode for daytime (10:00) and nighttime (22:00) conditions, respectively. The results for the UA and NLC modes are very similar except that the $\mathrm{O}_{3}$ is retrieved above $40 \mathrm{~km}$ instead of $20 \mathrm{~km}$. The ozone fields are included in these figures only for a reference to the noise and vertical resolution; its major features and the vertical and latitude distributions are discussed in Sect. 7 below. Two seasons are shown; the noise error and vertical resolution for the other two seasons are very similar.

The vertical resolution of the MIPAS retrieved ozone is given by the full width at half maximum of the averaging kernels rows. For daytime, the $\mathrm{O}_{3}$ average vertical resolution is 3-4 km below $70 \mathrm{~km}, 6-8 \mathrm{~km}$ at $70-80 \mathrm{~km}, 8-10 \mathrm{~km}$ at 80 $90 \mathrm{~km}$ (although it can be coarser in tropical regions), and 5-
$7 \mathrm{~km}$ at the secondary maximum $(90-100 \mathrm{~km})$. For nighttime conditions the vertical resolution is similar below $70 \mathrm{~km}$, and it is better in the upper mesosphere and lower thermosphere. It is $4-6 \mathrm{~km}$ at $70-100 \mathrm{~km}$ (except for a narrow region near $80 \mathrm{~km}$ where it takes values of $8-10 \mathrm{~km}), 4-5 \mathrm{~km}$ at the secondary maximum, and 6-8 km at $100-105 \mathrm{~km}$.

Two criteria are recommended to be used to screen the retrieved $\mathrm{O}_{3}$ version V5r_O3_m22 data in order to guarantee the quality of the profiles. First, the retrieved $\mathrm{O}_{3}$ values of individual profiles where the diagonal value (or the mean diagonal value when averaging) of the averaging kernel is less (in absolute value) than 0.03 are considered non-trustful. Second, those values corresponding to altitudes not sounded by MIPAS (below the lowermost tangent altitude) and flagged by the visibility flag should not be used.

The error budget described here considers the propagation of the measurement noise and of the uncertainties of model parameters onto the retrieved ozone abundances. Noiseinduced retrieval errors (as well as the vertical resolution; see above) are estimated routinely for each individual profile by the retrieval algorithm. The ozone noise error is calculated assuming a wavelength-dependent noise-equivalent spectral radiance which has approximated average values of 17 and $10 \mathrm{nW}\left(\mathrm{cm}^{2} \mathrm{~cm}^{-1} \mathrm{sr}\right)^{-1}$ for channels $\mathrm{A}$ and $\mathrm{AB}$, respectively. Typical values $(1 \sigma)$ for daytime (see the right column of Fig. 3) are smaller than $2 \%$ below $50 \mathrm{~km}, 2-10 \%$ between 50 and $70 \mathrm{~km}, 10-20 \%$ at $70-90 \mathrm{~km}$, and about $30 \%$ 
(a) DJF O3

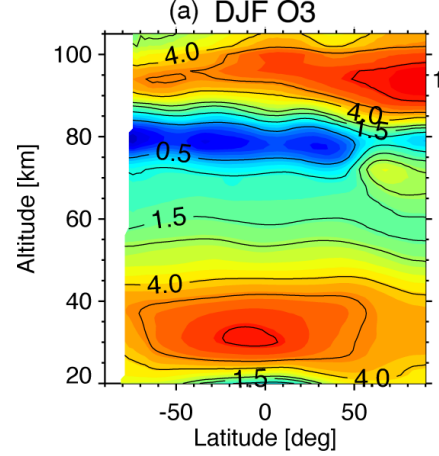

(d) MAM O3

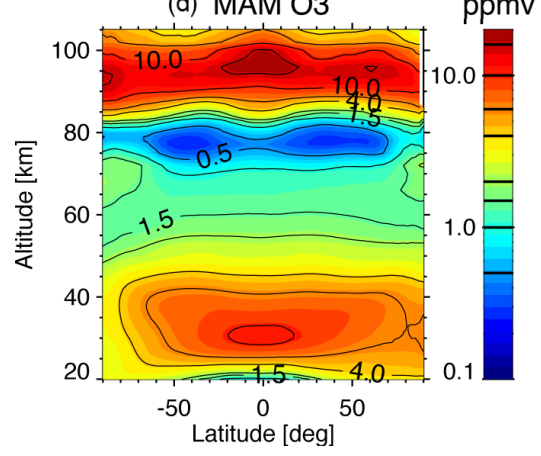

(b) Vert. res.

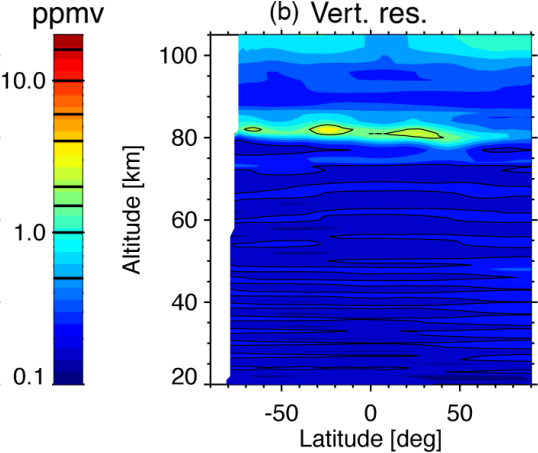

(e) Vert. res.

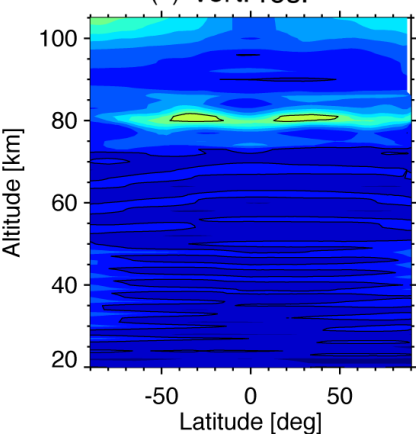

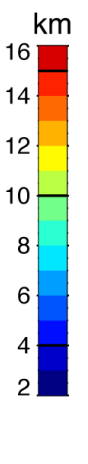
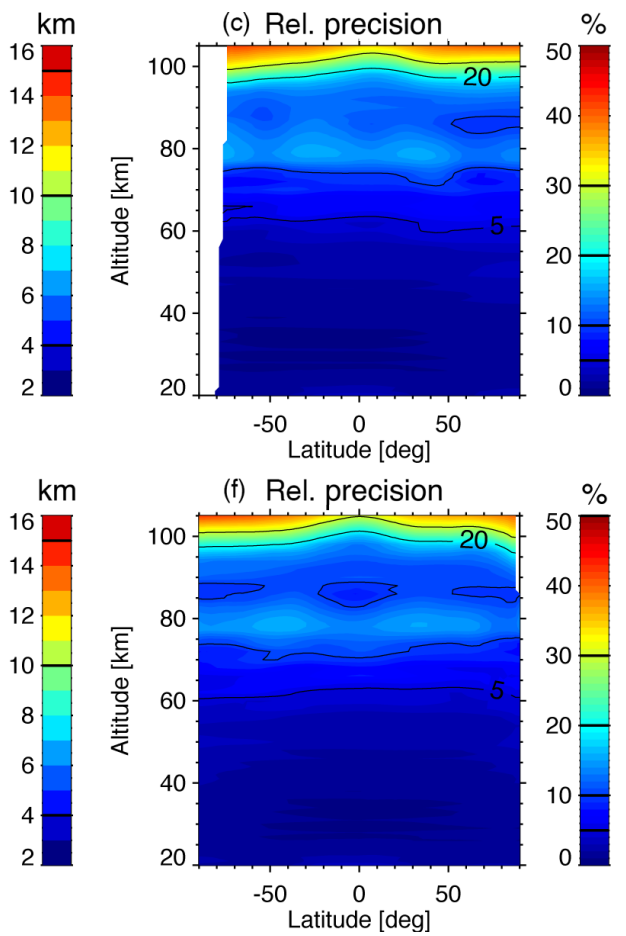

Figure 4. As Fig. 3 but for nighttime conditions.

above $95 \mathrm{~km}$. For nighttime (see right column of Fig. 4), the noise errors are very similar below around $70 \mathrm{~km}$ but significantly smaller above, being $10-20 \%$ at $75-95 \mathrm{~km}, 20-30 \%$ at $95-100 \mathrm{~km}$, and larger than $30 \%$ above $100 \mathrm{~km}$.

Errors related to the mapping of uncertain model parameters on the retrieved ozone VMR are estimated for representative profiles for daytime and nighttime conditions. We name these "systematic" errors to distinguish them from the noise error, although they are not purely systematic but in some cases they also have a random component. We have calculated them by comparing the retrieved profiles obtained with the nominal parameter and with the perturbed parameter. Figure 5 shows those errors $(1 \sigma)$, including also mean profiles of the noise errors shown in Figs. 3 and 4, and Table 4 lists them. The uncertainties assumed for the estimation of the systematic errors are $1 \%$ for gain calibration and $3 \%$ for the ILS. For the elevation pointing (LOS) we have assumed an error of $150 \mathrm{~m}$ below $60 \mathrm{~km}$, where we have information on the relative pointing from the temperature-LOS retrieval (von Clarmann et al., 2009; García-Comas et al., 2012). Above that height, where we obtain the LOS information from the engineering tangent altitudes of MIPAS (adjusted with the LOS retrieved below), we assumed an error of $300 \mathrm{~m}$. For temperature, the errors have been considered as $0.5 \mathrm{~K}$ below $50 \mathrm{~km}, 1 \mathrm{~K}$ at $50-70 \mathrm{~km}, 2 \mathrm{~K}$ at $70-80 \mathrm{~km}, 5 \mathrm{~K}$ at $80-100 \mathrm{~km}$, and $10 \mathrm{~K}$ above (García-Comas et al., 2014).

The spectroscopic errors have been estimated by J.-M. Flaud (personal communication, 2008). The errors assumed for the line intensities of the fundamental $v_{1}, v_{2}$, and $v_{3}$ bands (those mainly used here) are $2 \%$ for the strongest lines, $5 \%$ for the moderate lines, and $10 \%$ for the weaker lines. For the lines of the hot bands with a lower state of (010), (020), (100), or (001), the error is in the range of 4-25\%, increasing as the line intensity decreases. The errors considered for the more excited hot bands are larger, up to $30 \%$, but their contributions to the selected MWs is small. The error assumed for the $\mathrm{O}_{3}$ air-broadened half-widths is $12 \%$. The larger $\mathrm{O}_{3}$ spectroscopic errors below $50 \mathrm{~km}$ (see Fig. 5) are mainly due to the error in the half-widths. The contribution of the error in the line intensities is only $2-3 \%$.

The modelling of the non-LTE populations of the $\mathrm{O}_{3}$ vibrational levels emitting near $9.6 \mu \mathrm{m}$ is an important source of the MIPAS ozone systematic error above the midmesosphere. Non-LTE errors are dominated by the uncertainties in the collisional rates used in the non-LTE model. The three major sources are (1) the error in the three-body reaction rate of $\mathrm{O}_{3}$ formation, (2) the thermal relaxation of the $\mathrm{O}_{3}\left(v_{1}, v_{3}\right)$ levels with $\mathrm{N}_{2}$ and $\mathrm{O}_{2}$, and (3) the collisional relaxation and/or chemical reaction of $\mathrm{O}_{3}\left(v_{1}, v_{3}\right)$ levels with atomic oxygen. According to the current literature, we have considered uncertainties of $10 \%$ for the first, $20 \%$ for the second, and $50 \%$ for the third. For the latter, West et al. (1976) derived experimentally the deactivation rate of $\mathrm{O}_{3}\left(v_{1}, v_{3}\right)$ by $\mathrm{O}$ and provided rates for both the thermal relaxation, $\mathrm{O}_{3}\left(v_{1}, v_{3}\right)+\mathrm{O} \rightarrow \mathrm{O}_{3}+\mathrm{O}$, and the chemical reaction, $\mathrm{O}_{3}\left(v_{1}, v_{3}\right)+\mathrm{O} \rightarrow 2 \mathrm{O}_{2}$, assuming each one alone was responsible for the total deactivation. These authors could not estimate the relative contribution of each process and the er- 
(a) Day

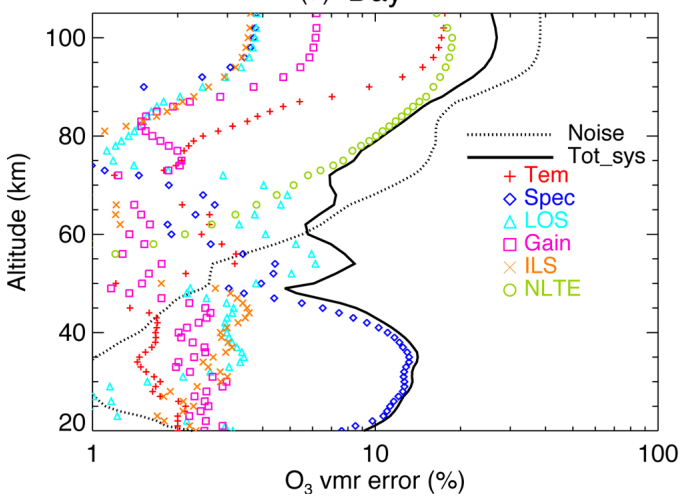

(b) Night

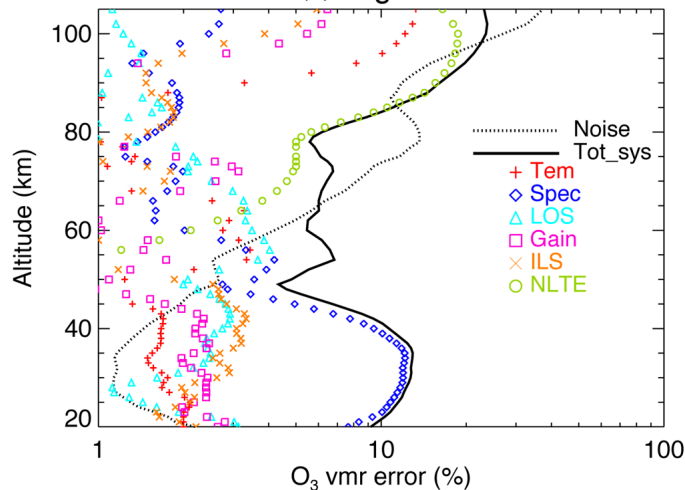

Figure 5. Errors of the retrieved $\mathrm{O}_{3}$ VMR for daytime (a) and nighttime (b) in relative values. The different sources are described in the legend of Table 4.

Table 4. Summary of main errors $(1 \sigma)$ of ozone VMR in percent. Errors refer to nighttime conditions with daytime values, when different, in parentheses. "NLTE" includes errors due to uncertainties in the collisional rates of the non-LTE model and in the atomic oxygen (see text). "Total (Syst.)" is the root sum square of all systematic errors (noise is not included). LOS stands for line of sight, "Tem" for temperature, ILS for instrument line shape, and "Spec." for spectroscopy.

\begin{tabular}{lrrrrrrrr}
\hline Height $(\mathrm{km})$ & Noise & LOS & Gain & Tem & ILS & Spec. & NLTE & Total (Syst.) \\
\hline 100 & $27(38)$ & $1.2(3.8)$ & $5.5(6.2)$ & $12(17)$ & 4.0 & $2.5(3.7)$ & 19 & $24(27)$ \\
95 & $17(36)$ & $1.4(3.5)$ & $2.1(5.6)$ & $9(15)$ & $1.8(3.3)$ & $1.4(3.3)$ & 18 & $21(25)$ \\
90 & $12(26)$ & $1.0(2.5)$ & $0.32(3.7)$ & $3.3(9.5)$ & $1.5(2.6)$ & 1.8 & 16 & $16(19)$ \\
80 & $14(15-20)$ & $0.8(1.3)$ & $0.34(1.6)$ & $0.8(2.5)$ & $1.5(0.9)$ & $1.6(0.6)$ & $6(10)$ & $6(11)$ \\
70 & $8.2(12)$ & $2.5(4)$ & $2.6(0.9)$ & $0.4(0.7)$ & $1.7(0.7)$ & 1.9 & 5 & $6.4(6.8)$ \\
60 & $4.2(5.5)$ & $3.5(4.1)$ & $1.0(1.4)$ & $2.8(2.4)$ & $0.7(0.9)$ & 2.0 & 2.0 & $5.5(5.7)$ \\
50 & 2.7 & $2.1(3.8)$ & $1.1(1.5)$ & 1.2 & 1.9 & $3.6(4)$ & 0 & $4.8(6)$ \\
40 & 1.5 & 2.7 & 2.2 & 1.7 & 3.1 & $9.4(11)$ & 0 & $11(12)$ \\
30 & 1.1 & 1.6 & 2.4 & 1.8 & 2.6 & 12 & 0 & 13 \\
20 & 2.2 & 3.1 & 2.6 & 2.0 & 2.2 & 7.6 & 0 & 9 \\
\hline
\end{tabular}

ror associated with these two rates is about $50 \%$. West et al. (1978) further reported that the deactivation is most likely to occur through the thermal relaxation. Hence, we have considered that the deactivation takes place through the thermal relaxation (process 2 in Table 1) and assumed the measured error of West et al. (1976) $50 \%$.

We have not considered additional errors due to the uncertainty in the atomic oxygen (daytime) or atomic hydrogen (nighttime) below $95 \mathrm{~km}$ (the error due to the $\mathrm{O}_{3}$ error itself is already taken into account). During daytime, this is reasonable because atomic oxygen is derived from the photochemical equilibrium with the retrieved $\mathrm{O}_{3}$. At night, however, when the retrieval depends on the atomic hydrogen concentration, if the error in $\mathrm{H}$ is significantly smaller than the $50 \%$ assumed for the deactivation of $\mathrm{O}_{3}\left(v_{1}, v_{3}\right)$, its contribution will not be significant. If comparable, however, we might be underestimating the non-LTE errors. Above $97 \mathrm{~km}$, we have assumed an uncertainty in the WACCM atomic oxygen of $50 \%$, leading to an error of about $10 \%$ in the retrieved $\mathrm{O}_{3}$ in that region (see Fig. 6). This error has been added, quadrat- ically, to the other components of the non-LTE uncertainties discussed above.

The uncertainty of the first of those three processes on $\mathrm{O}_{3}$ is only important above $\sim 85 \mathrm{~km}$, reaching a maximum of $5 \%$ in the retrieved $\mathrm{O}_{3}$. The second one is significant only from $\sim 60$ up to $\sim 80 \mathrm{~km}$, introducing an error of $2-5 \%$ in ozone for nighttime, and of $2-10 \%$ for daytime, including polar summer, where it might be slightly larger near $80 \mathrm{~km}$. The third one, including the error in the atomic oxygen, is only significant above $\sim 85 \mathrm{~km}$ but it is the largest, with an estimated error in $\mathrm{O}_{3}$ of $15-20 \%$ at $85-100 \mathrm{~km}$. Overall, the non-LTE errors are typically negligible below $60 \mathrm{~km}, 2-10 \%$ at $60-80 \mathrm{~km}$, and $15-20 \%$ above $85 \mathrm{~km}$.

The overall systematic component of the $\mathrm{O}_{3}$ abundance error is dominated by the spectroscopic data uncertainty below $50 \mathrm{~km}$ and by the non-LTE and temperature errors above about $70 \mathrm{~km}$. Between 50 and $70 \mathrm{~km}$, the pointing (LOS) and the spectroscopic errors are the dominant uncertainties. Our validation studies suggest, however, that the spectroscopic errors below $50 \mathrm{~km}$ are overestimated (see Sect. 6). 

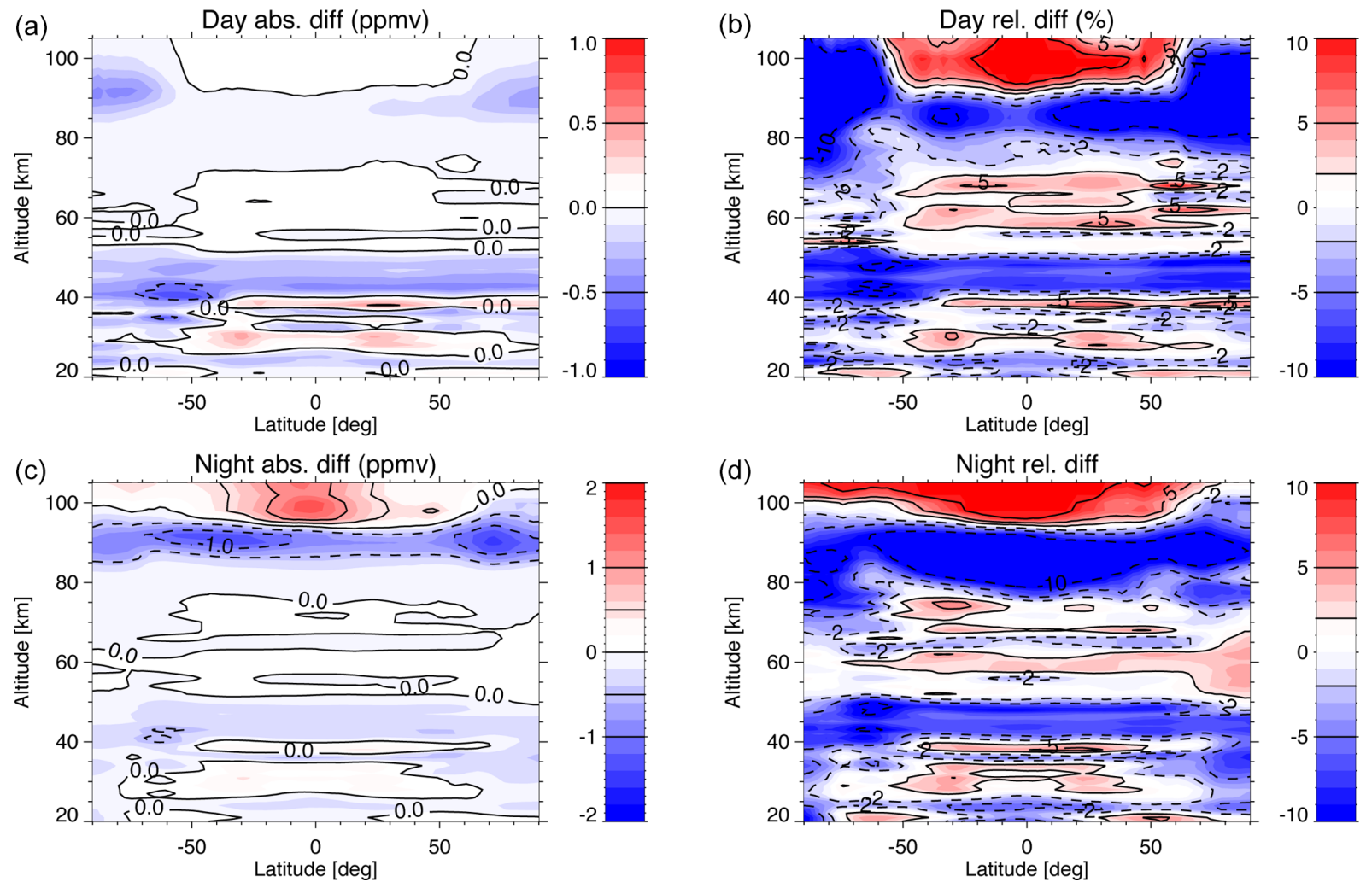

Figure 6. Comparison of $\mathrm{O}_{3}$ abundance retrieved in the current V5r_O3_m22 with the previous V4O_O3_m02 version for daytime conditions (10:00) (a, b) and nighttime (c, d). In absolute values (a, c) and in percent (b, d) of the older version (V5r_O3_m22V4O_O3_m02)/V4O_O3_m02, for all data taken in 2009.

\section{Differences between current V5r_O3_m22 and previous V4O_O3_m02 versions}

Since the previous V4O_O3_m02 version of MIPAS $\mathrm{O}_{3}$ has been used in some previous studies, (e.g. Smith et al., 2013, 2014), it is interesting to compare those results with the VMRs of this new V5r_O3_m22 version. The V5r_O3_m22 ozone retrieval setup has been improved with respect to the earlier in the following aspects.

First, the MIPAS L1b spectra have been updated from version 4.61/62 to version V5 (5.02/5.06). The spectroscopic data were upgraded from the HITRAN database version of 2004 to that of 2008. The retrieved kinetic temperature from MIPAS has also been changed to the temperature version of v5r_TLOS_m21 (see major differences discussed above). We have also improved the width of the integration window of the apodized ILS function. The uppermost altitude of the continuum retrieval has been expanded from 30 to $50 \mathrm{~km}$. The regularization scheme has been updated in order to make it compatible with that used in the nominal $\mathrm{O}_{3}$ retrieval (von Clarmann et al., 2013) in the common altitude range (up to $70 \mathrm{~km}$ ). The MWs have also been revised so that below $50 \mathrm{~km}$ we only use MWs located in channel A (see Table 3), like in NOM retrievals. We use a different distribution of the
$\mathrm{CO}_{2}$ abundance, now taken from WACCM (see above). The merging altitude of the daytime atomic oxygen derived from the ozone retrieval (assuming photochemical equilibrium) to the model (supplied for the region above) has been changed from 95 to $97 \mathrm{~km}$. At night we need, additionally, the $\mathrm{H}$ concentration, which has been taken from the NRLMSISE-00 model (Picone et al., 2002). In the previous version we took the nighttime $\mathrm{O}$ from the NRLMSISE-00 model in the whole altitude range. Above $97 \mathrm{~km}$ we use now the atomic oxygen from WACCM instead of that of NRLMSISE-00. An important update is the recalculation of the $\mathrm{O}_{3}$ vibrational temperatures during the iterations in the inversion process, following the update of the atomic oxygen. The $\mathrm{O}_{3}$ non-LTE model has also been improved, as described previously in Sect. 2 .

The average impact on the ozone retrieval after those changes (see Fig. 6) is an increase of 2-3\% (0.2-0.5 ppmv) below around $40 \mathrm{~km}$ (except in the polar winter, where there is a decrease). The clear increase around $40 \mathrm{~km}$ is due to the inclusion of the retrieval of the continuum for this altitude.

There is a clear decrease by $\sim 5-10 \%(\sim 0.4-0.5 \mathrm{ppmv})$ between 40 and $50 \mathrm{~km}$, principally induced by the use of MWs in channel A only (MWs in channel $\mathrm{AB}$ for these altitudes were removed). In the lower and middle mesosphere, $50-80 \mathrm{~km}$, there is an increase of about $2-5 \%(0.1-$ 
$0.2 \mathrm{ppmv}$ ). In the upper mesosphere, there is a general decrease of $\sim 0.5-1 \mathrm{ppmv}$ in nighttime conditions, principally caused by neglecting the removal of the excited $\mathrm{O}_{3}\left(v_{3}\right)$ by chemical reaction with atomic oxygen. This produces a larger population of $\mathrm{O}_{3}\left(v_{3}\right)$ and hence less $\mathrm{O}_{3}$. In daytime the effect is much smaller and has a smaller impact on the retrieved ozone (in absolute values). At altitudes above around $95 \mathrm{~km}$, the $\mathrm{O}_{3}$ in the new version is larger by about $5-10 \%$. This is caused by the use of the atomic oxygen from the WACCM model, which is larger than in NRLMSISE-00 and even overcomes the smaller relaxation of $\mathrm{O}_{3}\left(v_{3}\right)$ due to the chemical relaxation being ignored.

\section{Validation}

We have compared MIPAS V5r_O3_m22 ozone retrievals with co-located measurements from SABER, GOMOS, MLS, SMILES, and ACE-FTS. Comparisons for GOMOS are only for night conditions and in number density. For ACE-FTS, because it is an occultation instrument and $\mathrm{O}_{3}$ has very large diurnal variations around the terminator in the middle and upper mesosphere, we compare ACE sunset and sunrise with MIPAS observations with solar zenith angles (SZA) in the range of 88 to $92^{\circ}$. In order to select a pair of profiles to compare, we have selected measurements with universal time differences smaller than $2 \mathrm{~h}$ and distances smaller than $1000 \mathrm{~km}$. Considering an additional criterion of $1 \mathrm{~h}$ local time difference did not change the results significantly.

\subsection{Instruments}

\subsubsection{SABER}

SABER is a broadband radiometer flying on board the NASA's Thermosphere-Ionosphere-Mesosphere Energetics and Dynamics (TIMED) satellite, launched in December 2001 and starting operations in January 2002 (Russell et al., 1999). SABER measurements cover $83^{\circ} \mathrm{S}$ to $52^{\circ} \mathrm{N}$ and from $52^{\circ} \mathrm{S}$ to $83^{\circ} \mathrm{N}$, alternatively every 2 months. A $24 \mathrm{~h}$ local time coverage is completed approximately in 60 days. SABER observes the daytime and nighttime ozone limb emission at $9.6 \mu \mathrm{m}$, from which the ozone concentration is retrieved under non-LTE conditions from 10 to $100 \mathrm{~km}$. We use version 2.0 ozone here, publicly available at http: //saber.gats-inc.com (last access: December 2017). The nonLTE model used in SABER ozone retrievals is described in Mlynczak et al. (2013) and references therein. Similar to MIPAS, the retrieval of $\mathrm{O}_{3}$ from SABER requires knowledge of pressure, temperature, and atomic oxygen. The first two are taken from SABER retrievals of simultaneous measurements at $15 \mu \mathrm{m}$ (Remsberg, 2008; García-Comas et al., 2008). The atomic oxygen for SABER ozone retrievals is taken from NRLMSISE-00 (Picone et al., 2002). SABER ozone retrieval additionally needs to include the contribu- tion of one $\mathrm{CO}_{2}$ laser band emission in the ozone channel. For that it uses the $\mathrm{CO}_{2}$ vibrational temperatures computed during the SABER temperature retrieval. The vertical resolution of SABER ozone is approximately $2 \mathrm{~km}$. Given MI$\mathrm{PAS}_{3}$ coarser vertical resolution, particularly in the mesosphere, we used the MIPAS averaging kernels and a priori $\mathrm{O}_{3}$ to smooth SABER $\mathrm{O}_{3}$ profiles. Rong et al. (2009) report SABER ozone precision of $\approx 1-2 \%$ in the stratosphere and $\approx 3-5 \%$ in the lower mesosphere. The systematic errors range from $22 \%$ in the lower stratosphere to $\approx 10 \%$ in the lower mesosphere.

Previous comparisons between SABER v1.07 and MIPAS V4O_O3_m02 ozone VMRs in the mesosphere were performed by Smith et al. (2013). These showed the largest differences at the secondary maximum, which were attributed to the coarser MIPAS vertical resolution. They also mentioned that differences arose from the different SABER and MIPAS pressure/temperature profiles which affected conversion from density to VMR. The differences between SABER version 1.07 used in Smith et al. (2013) and version 2.0 (used here) are small (Smith et al., 2014).

\subsubsection{GOMOS}

GOMOS was a stellar occultation spectrometer on board the ESA's Envisat space platform (Bertaux et al., 2010). It operated from August 2002 to April 2012. Ozone density profiles are derived from GOMOS UV-visible measurements at $250-692 \mathrm{~nm}$ from 10 to $110 \mathrm{~km}$. GOMOS provides nighttime observations that are performed at around 22:00-23:00 LST at low latitudes. The latitudinal coverage eventually reaches the poles and slightly varies throughout the year due to varying distribution of stars used in the observations. The dataset used here was retrieved using ESA Instrument Processor Facility (IPF) version 6.01, described in Kyrölä et al. (2010b) and Sofieva et al. (2010), and is available under registration at the ESA Earth online portal (https://earth.esa.int, last access: December 2017). Unreliable profiles in the dataset have been screened out following recommendations of the GOMOS/6.01 Level 2 Product Quality Readme file. The user-friendly, open-access version of the GOMOS dataset (HARMOZ, Sofieva et al., 2013), which is screened for invalid data, is accessible at the Ozone_cci web page, http: //www.esa-ozone-cci.org/?q=node/161 (last access: December 2017). The vertical resolution of GOMOS ozone varies from $2 \mathrm{~km}$ in the lower stratosphere to $3 \mathrm{~km}$ in the upper stratosphere and above. Being better than the MIPAS vertical resolution, we have used MIPAS averaging kernels to smooth GOMOS profiles. Since GOMOS provides $\mathrm{O}_{3}$ number density but not $\mathrm{O}_{3}$ VMR, we compare GOMOS and MI$\mathrm{PAS}_{3}$ number densities. Random errors due to measurement noise and scintillations are $0.5-4 \%$ in the stratosphere and $2-10 \%$ in the mesosphere. Systematic errors are smaller than $2 \%$ and they are mainly due to $\mathrm{O}_{3}$ cross sections (Tamminen et al., 2010). 


\subsubsection{MLS}

The MLS was launched on July 2004 on the NASA's Earth Observing System Aura satellite (Waters et al., 2006). The equatorial crossings occur at 01:43/13:43 LT and the latitudinal coverage is between $82^{\circ} \mathrm{S}$ and $82^{\circ} \mathrm{N}$. Daytime and nighttime ozone profiles are derived from measurements of its thermal limb emission at $235.71 \mathrm{GHz}$ from the troposphere to $\approx 90 \mathrm{~km}$. However, its usable range is up to $0.02 \mathrm{hPa}$ or $\sim 72 \mathrm{~km}$ (see https://mls.jpl.nasa.gov/products/o3_product. php, last access: December 2017). The ozone dataset used here is version 4.2, downloaded from GES DISC (Schwartz et al., 2015) and described in Livesey et al. (2017) and references therein. The vertical resolution is $3 \mathrm{~km}$ in the stratosphere, $6 \mathrm{~km}$ in the middle mesosphere, and $9 \mathrm{~km}$ in the upper mesosphere. MLS ozone has generally indicated 5-10\% agreement with other datasets in the stratosphere. The estimated systematic uncertainty is $5-10 \%$ in the stratosphere, $10-20 \%$ in the lower mesosphere, and $20-50 \%$ in the middle mesosphere (Livesey et al., 2017). Due to the larger MLS $\mathrm{O}_{3}$ vertical resolution in the mesosphere, we have applied MLS averaging kernels and a priori information to the MIPAS ozone.

\subsubsection{SMILES}

SMILES was attached to the Exposed Facility of the JAXA's Japanese Experiment Module (JEM) of the International Space Station (ISS) and operated between October 2009 and April 2010 (Kikuchi et al., 2010). It measured ozone profiles from 16 to $85 \mathrm{~km}$ during daytime and to $96 \mathrm{~km}$ during nighttime, derived from measurements between 625 and $651 \mathrm{GHz}$ using the technique described in Mitsuda et al. (2011) and Takahashi et al. (2010, 2011). The latitudinal coverage is $38^{\circ} \mathrm{S}$ and $65^{\circ} \mathrm{N}$. We use version 3.2 of the data here, available at the Data Archives and Transmission System (DARTS) site (http://darts.isas.jaxa.jp/stp/smiles/, last access: December 2017). The vertical resolution is $3 \mathrm{~km}$ in the stratosphere, $4 \mathrm{~km}$ in the lower and mid-mesosphere, and $6 \mathrm{~km}$ at $95 \mathrm{~km}$. MIPAS and SMILES $\mathrm{O}_{3}$ vertical resolutions are similar and hence we did not apply averaging kernels to any of them. Previous versions of SMILES $\mathrm{O}_{3}(\mathrm{v} 2.2)$ agree with other measurements within $10 \%$ in the stratosphere and $30 \%$ in the mesosphere (Imai et al., 2013a, b).

\subsubsection{ACE-FTS}

The FTS is an infrared solar occultation Michelson interferometer flying on the CSA's ACE, also called Science Satellite (SciSat), launched in August 2003 (Bernath, 2017). It measures atmospheric absorption from the cloud top to $150 \mathrm{~km}$ during sunrise and sunset. The ACE orbit's high inclination results in coverage of the tropical, mid-latitude, and highlatitude regions over approximately 3 months. Ozone profiles are derived from measurements at several MWs be- tween 829 and $2673 \mathrm{~cm}^{-1}$ using the methodology described in Boone et al. (2013). We use version 3.5 of the data here. The retrievals are limited to the altitude range of 5 to $95 \mathrm{~km}$. The vertical resolution is $3-4 \mathrm{~km}$. The ACE-FTS version 3.5 $\mathrm{O}_{3}$ product agrees with MLS measurements to within $+4 \%$ from 20 to $45 \mathrm{~km}$. Compared to MLS, it exhibits a positive bias of up to $18 \%$ between 45 and $60 \mathrm{~km}$ and an increasing negative bias at higher altitudes (Sheese et al., 2017).

\subsection{Results of comparisons}

Figures 7 and 8 show the mean daytime and nighttime differences, respectively, between MIPAS and the different instruments (MIPAS - instrument) for the four seasons, grouped in four latitude bins. In addition, Figs. 9 and 10 show the global means, for all latitudes and seasons, for daytime and nighttime, respectively. The number of co-located pairs included in each mean difference profile is indicated as a subindex in the instrument's label. The mean altitude of the MIPAS $\mathrm{O}_{3}$ VMR primary and secondary maxima, coincident with the respective instrument, is also plotted as additional information.

In general, the agreement with all instruments, except SABER, is better than $5 \%$ below $50 \mathrm{~km}$ in all seasons for both daytime and nighttime, MIPAS $\mathrm{O}_{3}$ being larger (see Figs. 9 and 10). The differences around the ozone primary maximum (diamonds in the figures) are smaller than $5 \%$. These differences are well within MIPAS systematic errors (see Table 4). However, MIPAS (as the other instruments) measures less ozone than SABER below $50 \mathrm{~km}$, with values of $10-20 \%$ from 30 to $50 \mathrm{~km}$ and $5-15 \%$ at the stratospheric $\mathrm{O}_{3}$ maximum.

At altitudes from 50 to $65-70 \mathrm{~km}$, we also find a good general agreement with all instruments, except SABER at 60 $70 \mathrm{~km}$, and MLS at $65-70 \mathrm{~km}$ in some latitudes and/or seasons. The differences are smaller than 5-10\% in all seasons both during daytime and nighttime, with MIPAS $\mathrm{O}_{3}$ generally being larger (see Figs. 9 and 10). These differences are within or just at the edges of the MIPAS systematic errors (grey shading in the figures). Opposite to that behaviour, MIPAS is smaller (5-10\%) than ACE-FTS in the altitude range of $45-55 \mathrm{~km}$ (see Fig. 9). This is likely the effect of the known positive bias of ACE-FTS $\mathrm{O}_{3}$ in this region (Sheese et al., 2017). MIPAS measures up to $10 \%$ (nighttime) and up to $20 \%$ (daytime) less ozone than SABER from 50 to $60 \mathrm{~km}$. These differences increase above $60 \mathrm{~km}$ and are discussed below.

Exceptions to that general behaviour are the larger differences found with MLS at $65-70 \mathrm{~km}$ in daytime in spring (at $30-50^{\circ}$ ) and autumn and winter for most latitudes. Differences with SMILES are also exceptionally larger at 60 $80 \mathrm{~km}$ during nighttime in winter at $70-90^{\circ}$ but, with only eight coincidences, they are not statistically significant.

A positive bias in SABER stratospheric $\mathrm{O}_{3}$, version 1.07, was previously reported by Rong et al. (2009). Differences 

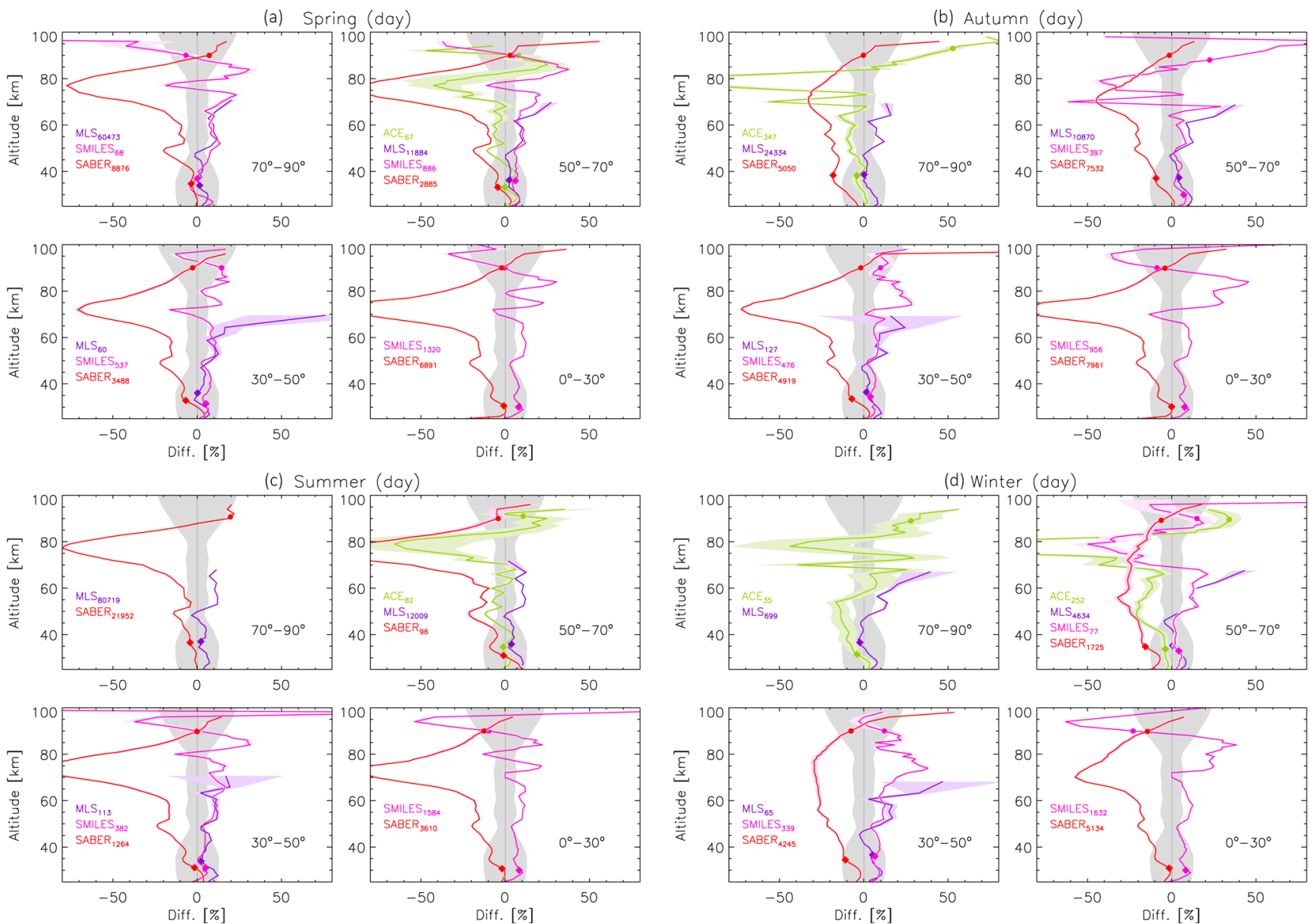

Figure 7. Mean of the daytime $\mathrm{O}_{3}$ VMR differences (MIPAS-instrument) in \% of MIPAS between co-located pairs of measurements of MIPAS (MA mode) with ACE-FTS (green), SABER (red), MLS (purple), and SMILES (magenta) for spring (MAM for NH and SON for SH) (a), autumn (SON for NH and MAM for SH) (b), summer (JJA for NH and DJF for SH) (c), and winter (DJF for NH and JJA for SH) (d). The symbols indicate the mean altitude of the MIPAS $\mathrm{O}_{3}$ VMR primary (diamonds) and secondary (circles) maxima coincident with the respective instrument. The numbers of coincidences are indicated in the subscripts. The grey shaded area shows the MIPAS systematic errors. The colour-shaded areas (hardly noticeable in many cases) are the standard errors of the mean of the differences.

in temperature cannot explain this bias because they are 1$2 \mathrm{~K}$ larger than MIPAS below $30 \mathrm{~km}$ (which would result in less $\mathrm{O}_{3}$ ) and are in excellent agreement (within $1 \mathrm{~K}$ ) from 30 to $85 \mathrm{~km}$ (García-Comas et al., 2014). Some tests have shown the retrieval of MIPAS $\mathrm{O}_{3}$ at these altitudes using MWs in the $\mathrm{AB}$ channel, e.g. the $10 \mu \mathrm{m}$ spectral region where SABER measures, results in an $10 \%$ ozone increase (see Sect. 5 and Fig. 6). Thus, $\mathrm{O}_{3}$ spectroscopic errors in the $10 \mu \mathrm{m}$ region could be the reason for the larger SABER stratospheric ozone. Indeed, MIPAS and SABER measurements have a better agreement at $50 \mathrm{~km}$ (altitude above which MIPAS uses AB channel MWs) than at lower altitudes, whereas MIPAS differences with instruments other than SABER increase to $10 \%$ above that altitude.

Between 50 and $85 \mathrm{~km}$ MIPAS and SABER ozone profiles show similar vertical gradients but shifted (not shown). In this region ozone decreases with altitude to very small val- ues and hence the relative differences are rather large. At $60-85 \mathrm{~km}$ they are within $20-80 \%$ in daytime and $10-40 \%$ at night, MIPAS ozone being smaller. A daytime SABER ozone overestimation at these altitudes was already reported by Smith et al. (2013). A likely explanation for the larger SABER $\mathrm{O}_{3}$ values could be the faster deactivation of the $\mathrm{O}_{3}$ $v_{1}$ and $v_{3}$ manifold by $\mathrm{N}_{2}$ and $\mathrm{O}_{2}, k_{\mathrm{vt}, \mathrm{M}}$ in Table 1 . According to Mlynczak et al. (2013), the SABER retrieval uses the values reported by Martin-Torres (1999), which are about a factor of 2 faster than those measured by Menard et al. (1992), which are used here. A faster collisional rate gives rise to smaller $\mathrm{O}_{3}\left(v_{3}\right)$ vibrational temperatures and hence to larger retrieved $\mathrm{O}_{3}$ VMR. The fact that the non-LTE deviation of $\mathrm{O}_{3}\left(v_{3}\right)$ vibrational temperatures from the kinetic temperature is larger in daytime than at night could explain the larger daytime bias. 

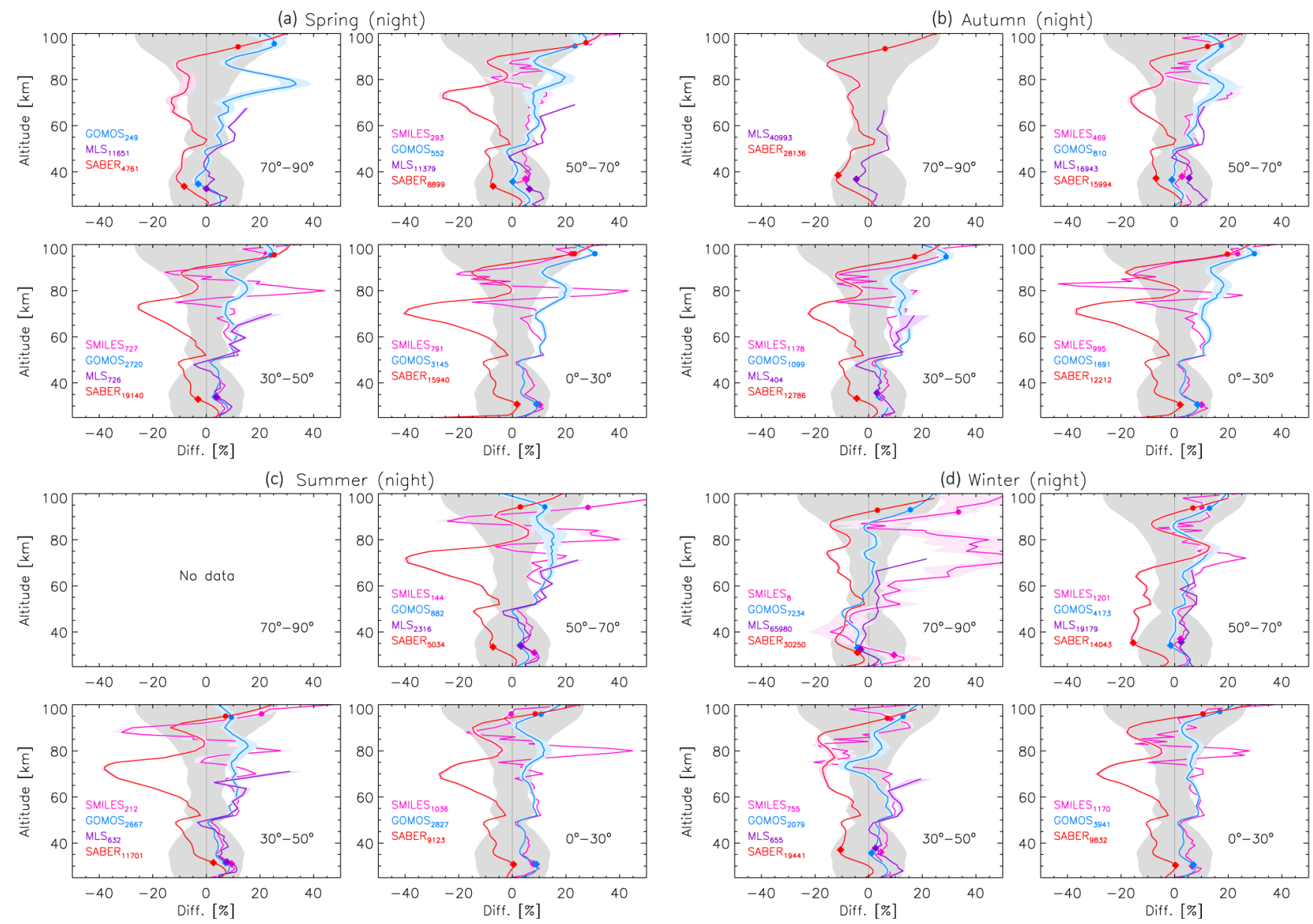

Figure 8. As Fig. 7 but for nighttime $\mathrm{O}_{3}$. Instrument colours are the same except that ACE-FTS is replaced by GOMOS (light blue).

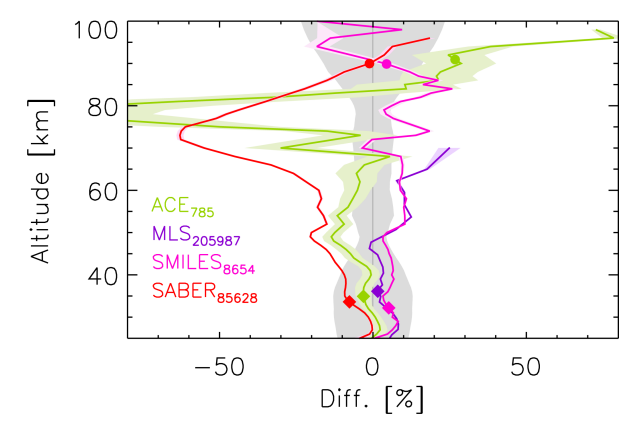

Figure 9. Global mean (for all latitudes and seasons) of the daytime $\mathrm{O}_{3}$ VMR differences (MIPAS-instrument) in percent of MIPAS between co-located pairs of measurements of MIPAS (MA mode) with ACE-FTS (green), SABER (red), MLS (purple), and SMILES (magenta). For more details, see caption of Fig. 7.

MIPAS differences with other instruments are larger above $70 \mathrm{~km}$ than below. These differences are of $10-20 \%$ with SMILES and GOMOS (nighttime). When compared with ACE-FTS, MIPAS $\mathrm{O}_{3}$ is significantly smaller $(<-50 \%)$ near $80 \mathrm{~km}$ (see Fig. 9). This large relative difference is in

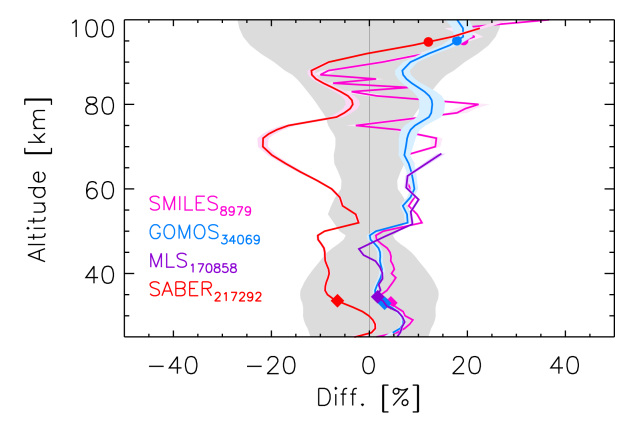

Figure 10. As Fig. 9 but for nighttime $\mathrm{O}_{3}$. Instrument colours are the same except that ACE-FTS is replaced by GOMOS (light blue).

part caused by the very small values of $\mathrm{O}_{3}$. The difference in absolute values is smaller than $0.1 \mathrm{ppmv}$. Also, the difference could be due to different solar illuminations along the LOS of both instruments.

In the polar winter around $70 \mathrm{~km}$, where the tertiary maximum develops (see Sect. 7), MIPAS agreement with GOMOS is excellent (3\%) (see Fig. 12, winter at $70-90^{\circ}$ ). MI- 
PAS and GOMOS lie between the rest of the other instruments, being on average $10 \%$ smaller than SABER (night), $20 \%$ larger than MLS (during night), within $\sim 30 \%$ of ACEFTS (terminator), and $50 \%$ larger (although with a very few coincidences) than SMILES (night). Smith et al. (2013) reported that $\mathrm{O}_{3}$ from SABER version 1.07 did not exhibit a tertiary maximum, which contrasts with version 2.0 in which SABER shows the largest ozone tertiary maximum of all the instruments considered.

At altitudes above $85-90 \mathrm{~km}$ during nighttime the differences increase with altitude and are generally larger. In the case of MIPAS and SABER the differences are partially due to a vertical shift of $1-2 \mathrm{~km}$ (not shown).

At the altitude of the secondary maximum, the agreement between all instruments for daytime conditions is very good, except ACE-FTS in autumn and winter. MIPAS daytime ozone differences with SABER and SMILES are within 5 and $10 \%$, respectively, except for low latitudes in the solstices $(10 \%)$ and summer high latitudes $(20 \%)$ for SABER and autumn high latitudes and winter low latitudes ( $20 \%)$ for SMILES. MIPAS ozone is generally larger than that of ACE (by a mean of $\sim 20-30 \%$ ) at this altitude. This difference can be partially due to the different illumination conditions along the LOS of both instruments. We performed a test, restringing MIPAS data to SZA $<85^{\circ}$, and the difference was reduced to just $10 \%$ (0.2-0.3 ppmv).

During nighttime, however, MIPAS ozone is between 5 and $25 \%$ larger than the other instruments around the secondary maximum. The differences somehow vary with season, being largest in spring and autumn. MIPAS ozone is 10$20 \%$ larger than SABER and SMILES and 10-25\% larger than GOMOS.

At altitudes above around $93 \mathrm{~km}$, this larger MIPAS nighttime ozone is most likely caused by the large atomic oxygen in WACCM. If using the MSIS atomic oxygen in this region those differences would be reduced by $10-15 \%$ (see Figs. 7 and 8).

Overall, focusing on Figs. 9 and 10, MIPAS $\mathrm{O}_{3}$ has an accuracy better than $5 \%$ at and below $50 \mathrm{~km}$, with a positive bias of only a few percent. In the $50-75 \mathrm{~km}$ region, MIPAS $\mathrm{O}_{3}$ has a positive bias of approximately $10 \%$, possibly caused by spectroscopic errors. Between 75 and $90 \mathrm{~km}$, nighttime MIPAS $\mathrm{O}_{3}$ is within $10 \%$ of SABER and SMILES $\mathrm{O}_{3}$ but has a positive bias of about $10 \%$ with respect to GOMOS. In this region, during daytime, the relative differences are larger, with a positive difference of 10-20\% with SMILES and negative difference of $10-50 \%$ with ACE and SABER. Given that ACE measures at the terminator and SABER daytime $\mathrm{O}_{3}$ has a known positive bias, we think that MIPAS $\mathrm{O}_{3}$ in this region is accurate to within 10-20\%. Above $90 \mathrm{~km}, \mathrm{MIPAS} \mathrm{O}_{3}$ in daytime is in agreement with other instruments by $10 \%$. At night, however, it shows a positive bias increasing from $10 \%$ at $90 \mathrm{~km}$ to $20 \%$ at 95 $100 \mathrm{~km}$, which is attributed to the large atomic oxygen of WACCM.

\section{Climatology}

The MIPAS middle atmosphere $\mathrm{O}_{3}$, with a global (pole-topole) latitude coverage and day- and nighttime measurements taken at two fixed local times, spanning the altitude range from 20 to $100 \mathrm{~km}$, represents a very important dataset for studying the middle atmosphere. In this section we present some ozone distributions, represented against altitude, latitude and time, showing the major $\mathrm{O}_{3}$ features in the middle and upper mesosphere.

Figures 11 and 12 show composite monthly zonal means of MIPAS $\mathrm{O}_{3}$ data for the 2007-2012 period for day- and nighttime, respectively. Here we consider "daytime" the measurements with a SZA smaller than the SZA of the terminator, $\mathrm{SZA}_{\text {ter }}(z)=180-\arcsin \left(R_{\oplus} /\left(R_{\oplus}+z\right)\right) 180 / \pi\left(R_{\oplus}\right.$ is the Earth's radius and $z$ is altitude), decreased in $3^{\circ}$, and taken at 10:00 LT. The decrease in $3^{\circ}$ was done to avoid scans partially in dark conditions. "Nighttime" is taken when the observed altitude is in dark conditions, $\operatorname{SZA}(z)>\operatorname{SZA}_{\text {ter }}(z)$, and the measurements are taken at a local time of 22:00 LT. Those figures show the typical primary, secondary, and tertiary maxima and their seasonal evolution.

The latitudinal-seasonal distribution of daytime $\mathrm{O}_{3}$ in the secondary maximum, near $90-95 \mathrm{~km}$, shows maxima near the polar winters (November-February in the Northern Hemisphere (NH) and May-August in the Southern Hemisphere (SH)) (Fig. 11).

In general we observe a minimum in the daytime $\mathrm{O}_{3}$ secondary maximum near the tropics (except perhaps for October) which is attributed to tidal effects (see e.g. Marsh et al., 2002; Dikty et al., 2010). The diurnal tertiary maximum, taking place usually around $60-75 \mathrm{~km}$ (Fig. 11), occurs during the winter seasons polewards of $60-70^{\circ}$.

The ozone secondary maximum at night presents larger values near the polar winters, more precisely in the early polar winters (e.g. November in the $\mathrm{NH}$ and May in the $\mathrm{SH}$ ). This polar winter maximum decreases as the season progresses in both hemispheres and starts recovering near the end of the winter (February in the $\mathrm{NH}$ and August in the $\mathrm{SH}$ ). This is in agreement with the results reported by Smith et al. (2014). These investigators have shown that this $\mathrm{O}_{3}$ enhancement is caused by the relatively weak meridional circulation at those times/regions, which leads to low temperatures and low $\mathrm{H}$ concentrations, both favouring the production of $\mathrm{O}_{3}$.

Thus, during solstice, the $\mathrm{O}_{3}$ secondary maximum shows a clear latitudinal gradient, growing from summer to winter. During the equinox months, the nighttime secondary maximum exhibits large $\mathrm{O}_{3}$ values across all latitudes, reaching the highest values in April and October. In the equinox months of March, April, September, and October, the signature of the diurnal migrating tide is apparent near the Equator. Larger values are found near the Equator than at adjacent latitudes near $75-80 \mathrm{~km}$, then smaller around $85-87 \mathrm{~km}$, and larger again near $95 \mathrm{~km}$. The signature is more clearly seen in April and October when the largest values of the ozone sec- 

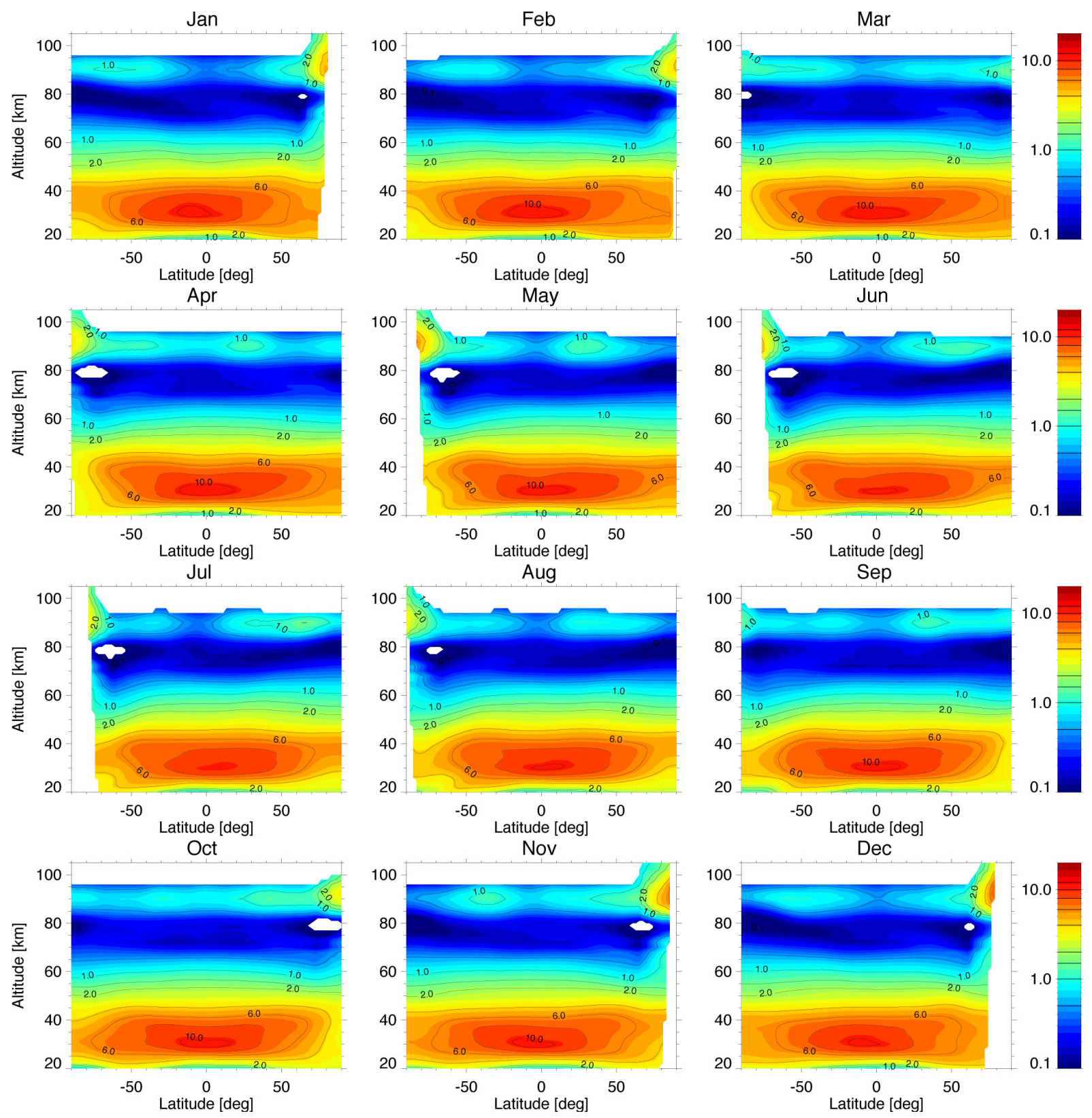

Figure 11. Composite monthly zonal mean of MIPAS data taken in the MA mode for the 2007-2012 period for daytime (local time of 10:00). White areas denote regions where MIPAS has no sensitivity to measure the very low ozone values. Contours are $0.1,0.5,1,1.5,2,4,6,8$, 10 , and 12 ppmv.

ondary maximum are observed at the Equator near $95 \mathrm{~km}$, reaching up to about $20 \mathrm{ppmv}$. The nighttime tertiary maximum has larger values than during daytime (see Fig. 12) and it is usually shifted equatorwards. These values are in good agreement with the measurements of the nighttime tertiary maximum measured by GOMOS (Sofieva et al., 2009). At latitudes poleward of the terminator it is usually displaced to lower altitudes. Although not clearly noticeable (because of the scale) in Fig. 12, the nighttime tertiary maximum is slightly larger in the $\mathrm{NH}$ than in the $\mathrm{SH}$, as reported by Smith et al. (2018).

For completeness we also show the composite seasonal zonal mean of the MIPAS $\mathrm{O}_{3}$ diurnal differences (10:00-22:00 LT in percentage of 22:00 LT measurements) in Fig. 13. The day-night differences below about $50 \mathrm{~km}$ are very small, generally between $\pm 2 \%$. These differences are within the range of other measurements and model predictions, (see, for example, Schanz et al., 2014; Studer et al., 2014; Sakazaki et al., 2013; Parrish et al., 2014; Moreira 

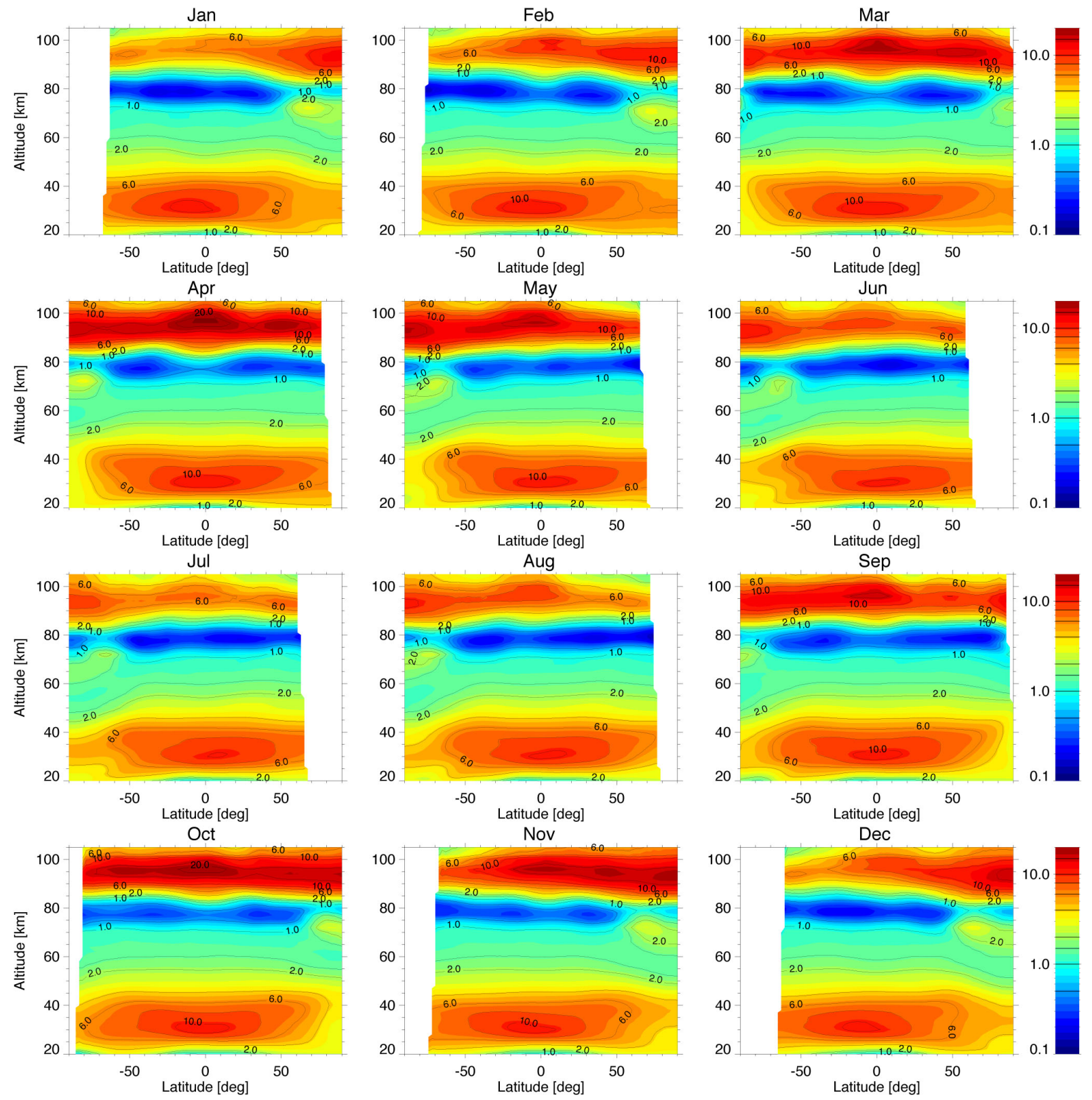

Figure 12. Composite monthly zonal mean of MIPAS data for the 2017-2012 period for nighttime. Contours are 0.5, 1, 1.5, 2, 4, 6, 8, 10, 15 , and 20 ppmv.

et al., 2017). This overall good agreement in the MIPAS $\mathrm{O}_{3}$ diurnal variation with other measurements supports the good quality of MIPAS data in this LTE region. Above about 45$50 \mathrm{~km}$ the effects of photodissociation start becoming important, showing a decline in the daytime $\mathrm{O}_{3}$ with respect to the nighttime at most latitudes (more pronounced near the tropics) and seasons except near the polar regions. The diurnal differences increase with altitude. At $\sim 80 \mathrm{~km}$ the daynight differences are mainly ruled by the nighttime $\mathrm{O}_{3}$ variations, which are largely controlled by the semi-annual oscillation (SAO) (see below) and the tidal motions changing the atomic oxygen and hence $\mathrm{O}_{3}$. In the polar summer terminator near $80 \mathrm{~km}$, daytime $\mathrm{O}_{3}$ at 10:00 LT exceeds $\mathrm{O}_{3}$ at 22:00 LT. Above $90 \mathrm{~km}$, nighttime $\mathrm{O}_{3}$ is significantly larger.

\subsection{Annual variability}

Figure 14 shows the annual variability as latitude-month cross sections of $\mathrm{O}_{3}$ at different altitudes for daytime (left column) and nighttime (right column).

At $40 \mathrm{~km}$ MIPAS observes larger $\mathrm{O}_{3}$ values in the tropics and mid-latitudes compared to the polar regions, as well as lower values in the $\mathrm{SH}$ polar winter compared to the $\mathrm{NH}$ 

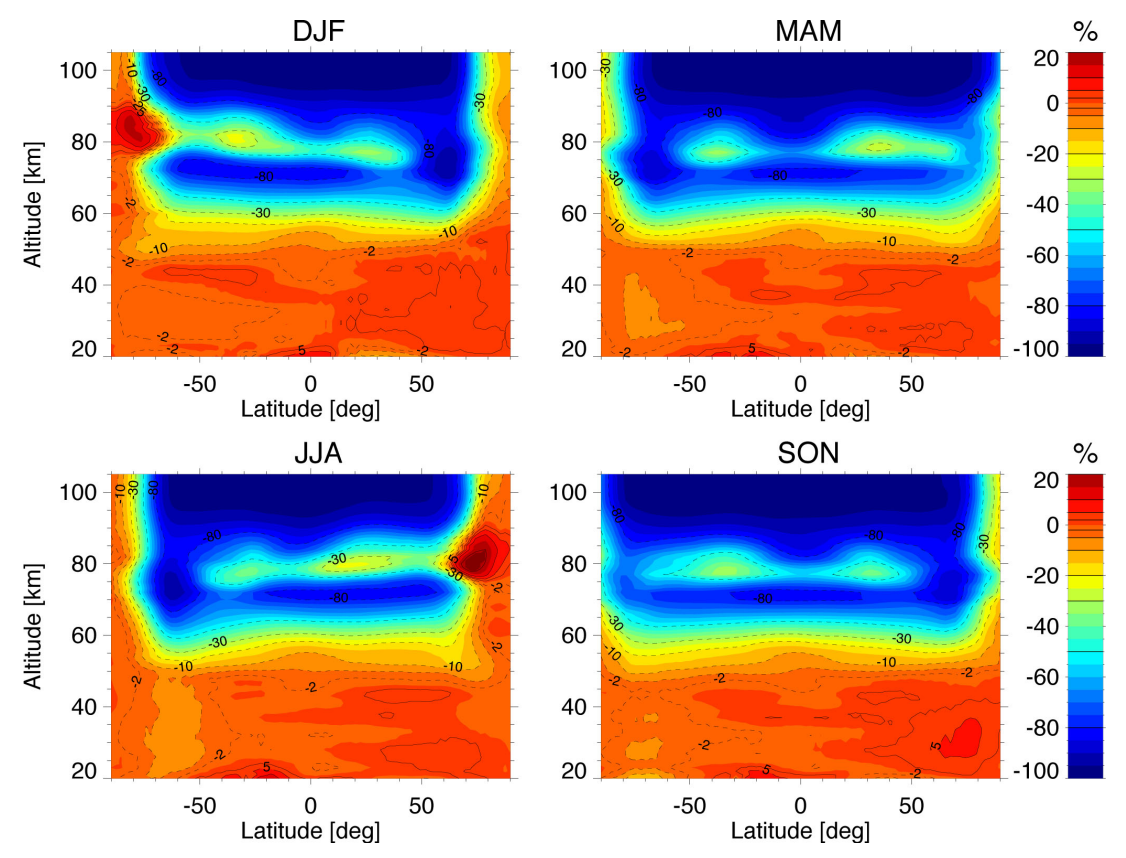

Figure 13. Composite seasonal zonal mean of $\mathrm{O}_{3}$ diurnal differences (10:00-22:00 LT in percentage of 22:00 LT measurements) of MIPAS data taken in the MA mode for the 2007-2012 period. DJF stands for December, January, and February; MAM for March, April, and May; JJA for June, July, and August; and SON for September, October, and November. Contours are $-80,-50,-30,-20,-10,-5,-2,2,5,10$, and $20 \%$.

winter. Around the Equator we observe slightly larger values during solstice conditions (January and July) than at equinox (April and October). Maximum values also occur at midlatitudes $\left(30-40^{\circ}\right)$ during May-June and September in the $\mathrm{SH}$ and during August and September in the NH. The daynight differences are small, with ozone slightly larger during daytime, more noticeable in the $\mathrm{NH}$.

At $60 \mathrm{~km}$ the day-night differences are very marked, with smaller daytime ozone values due to losses by photodissociation. This pattern, due to illumination conditions, is very clear in the second panel of the first column.

At $70 \mathrm{~km}$, the structure of the $\mathrm{O}_{3}$ tertiary maximum (second column, third panel) in the SH polar winter is very obvious, exhibiting a "ring" shape following the terminator. The tertiary maximum has larger values in the early winter, then decreases and increases again at the end of the winter. Note also the higher values of the tertiary maximum in the $\mathrm{NH}$ polar winter (as discussed above). These results are consistent with the recent analysis of the tertiary maximum carried out by Smith et al. (2018).

The $\mathrm{O}_{3}$ latitude-month distribution near $80 \mathrm{~km}$ shows during equinox conditions significant increases at mid-latitudes during daytime and in the tropics at night, which seem to be caused by tides. Near the polar regions, the nighttime $\mathrm{O}_{3}$ at $80 \mathrm{~km}$ shows similar features to the tertiary maximum described above, with larger values early in the winter in both hemispheres, and is larger in the $\mathrm{NH}$.
At $90 \mathrm{~km}$, the nighttime $\mathrm{O}_{3}$ in the polar winter shows a more marked seasonal evolution than at lower altitudes, with much larger values in the early winter as has been shown by Smith et al. (2014). The SAO is also evident in the tropics and at mid-latitudes (see e.g. Garcia et al., 1997). Similar features have also been observed by GOMOS (Kyrölä et al., 2010a). Even though $\mathrm{O}_{3}$ has a short lifetime, and hence it is not significantly advected, its distribution responds to changes in temperature, atomic oxygen, and other species associated with the SAO. As a result of both effects ozone shows a kind of "U-shape" distribution at this altitude.

\subsection{Altitude-resolved time series}

In order to study the inter-annual variability We show in this section altitude-resolved time series of $\mathrm{O}_{3}$ at the tropical and polar latitudes (Fig. 15) and as latitude-time cross sections at given altitudes (Fig. 16). We see clearly the SAO above around $75 \mathrm{~km}$ in both day- and nighttime in the upper panels of Fig. 15. We also observe in these panels that the $\mathrm{O}_{3}$ secondary maximum is located at higher altitudes in nighttime than during daytime. In addition, there is a hint that the daytime $\mathrm{O}_{3}$ secondary maximum shows the lowest concentrations close to the solar cycle minimum in 2009/2010, which is also visible in the bottom/left panel of Fig. 16.

Focusing on the polar regions (middle and bottom panels of Fig. 15), we observe that the stratospheric maximum $(25-40 \mathrm{~km})$ is slightly larger in the NH polar region than in the SH polar region. As discussed above, the nighttime ter- 
(a)
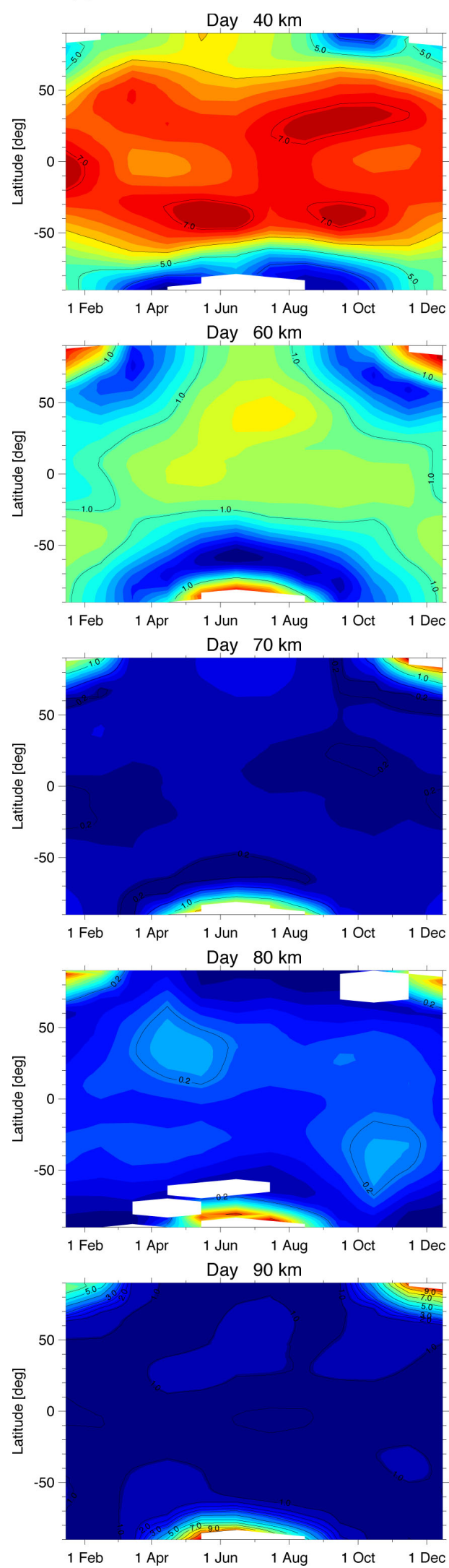

(b)
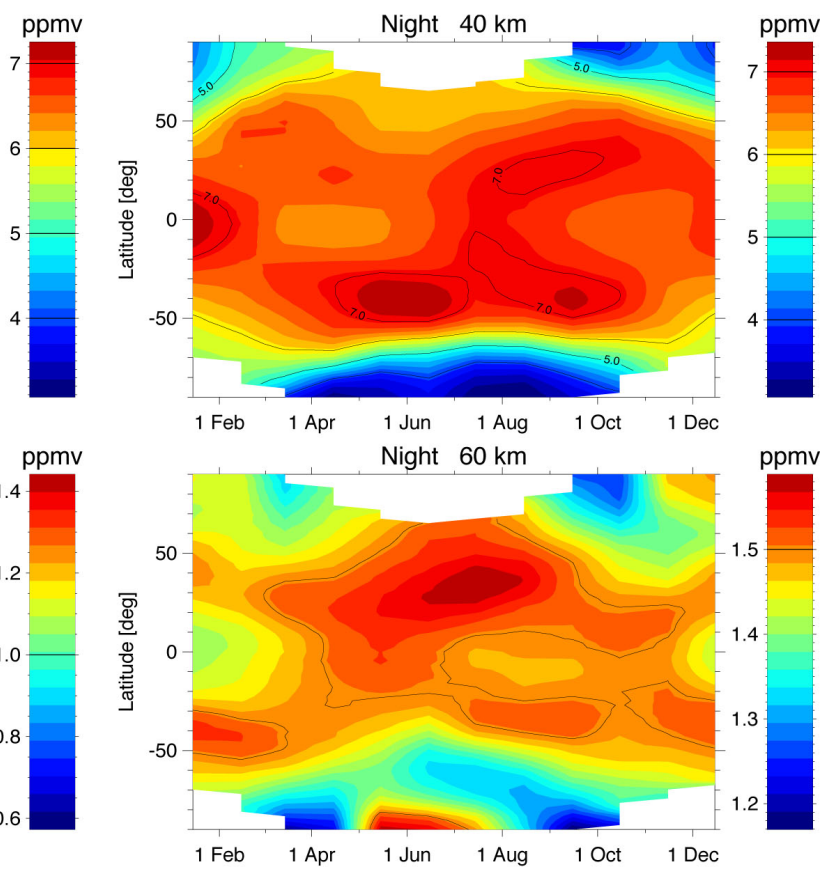

ppmv

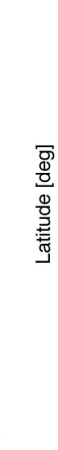
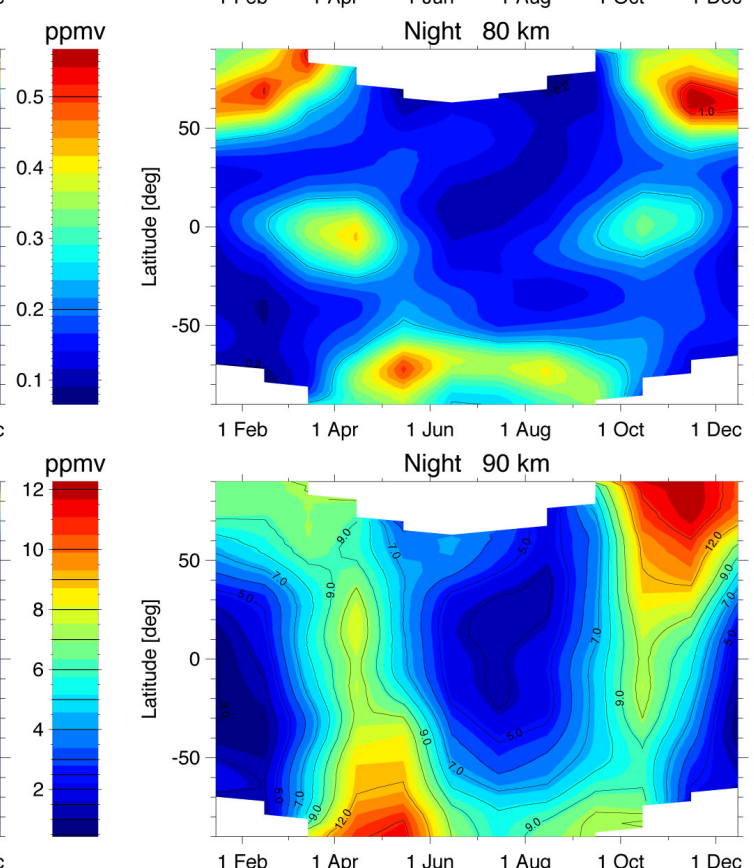

Figure 14. Seasonal evolution vs. latitude of $\mathrm{O}_{3}$ VMR at different altitudes for daytime (a) and nighttime (b). Note the different scales used in the different panels. 

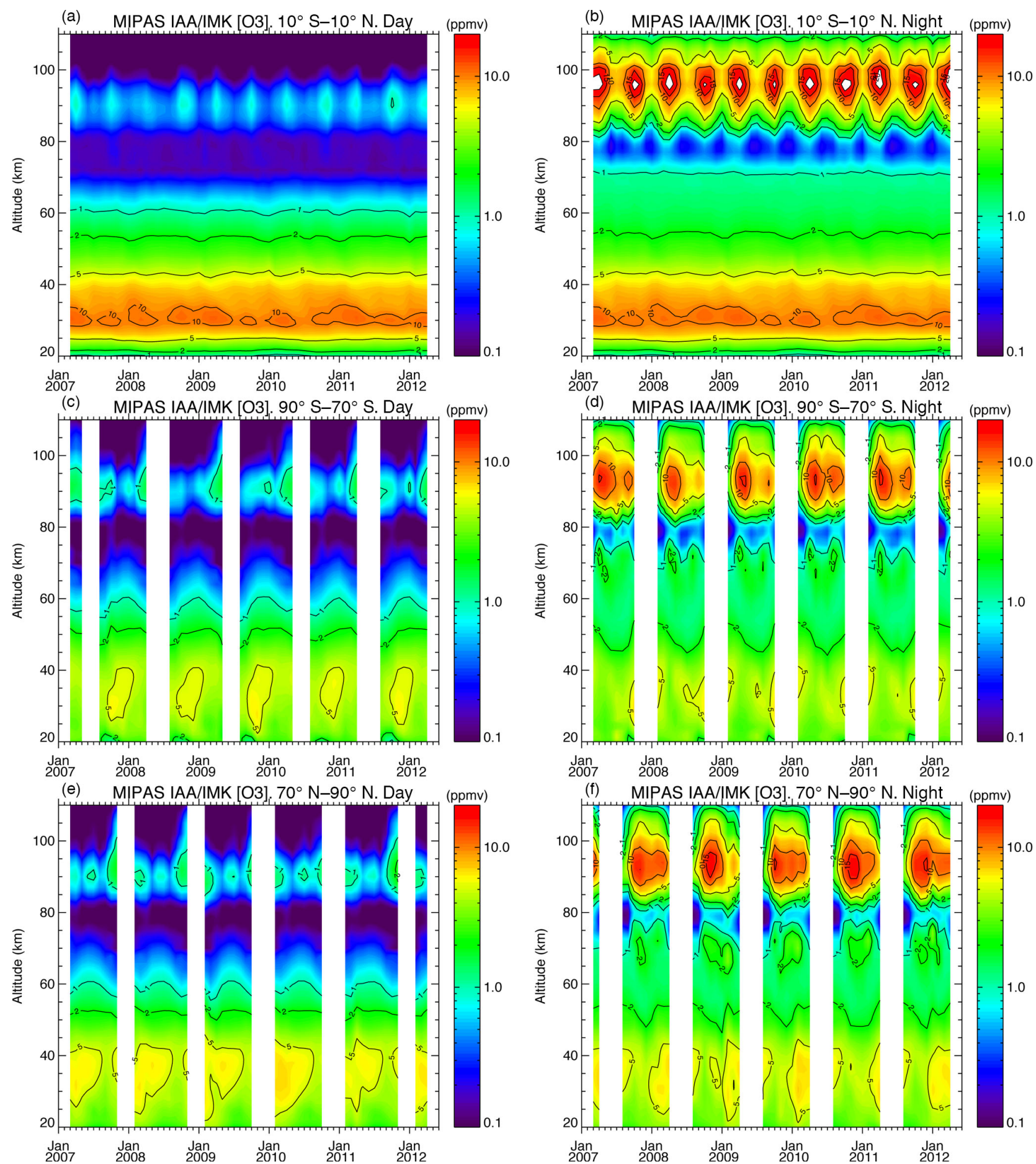

Figure 15. Altitude-resolved series for latitudes near the Equator $\left(10^{\circ} \mathrm{S}-10^{\circ} \mathrm{N}\right)(\mathbf{a}, \mathbf{b})$, the southern polar region $\left(70-90^{\circ} \mathrm{S}\right)(\mathbf{c}, \mathbf{d})$, and the northern polar region $\left(70-90^{\circ} \mathrm{N}\right)(\mathbf{e}, \mathbf{f})$, for daytime (left column) and nighttime (right column).

tiary maximum is slightly larger in the $\mathrm{NH}$ than in the $\mathrm{SH}$ polar region. In the SH it shows a double peak in each winter (early and late in the winter) while in the $\mathrm{NH}$ it is not so pronounced. Moving to higher altitudes, the nighttime $\mathrm{O}_{3}$ secondary maximum shows a clear winter variability, with larger values early in the winter. The double peak structure appearing each winter is very evident in the $\mathrm{SH}$, as it is in the tertiary maximum, but not so clear in the $\mathrm{NH}$.

Figure 16 shows that the diurnal variation is clearly seen already at $50 \mathrm{~km}$ at the tropics and mid-latitudes, with 

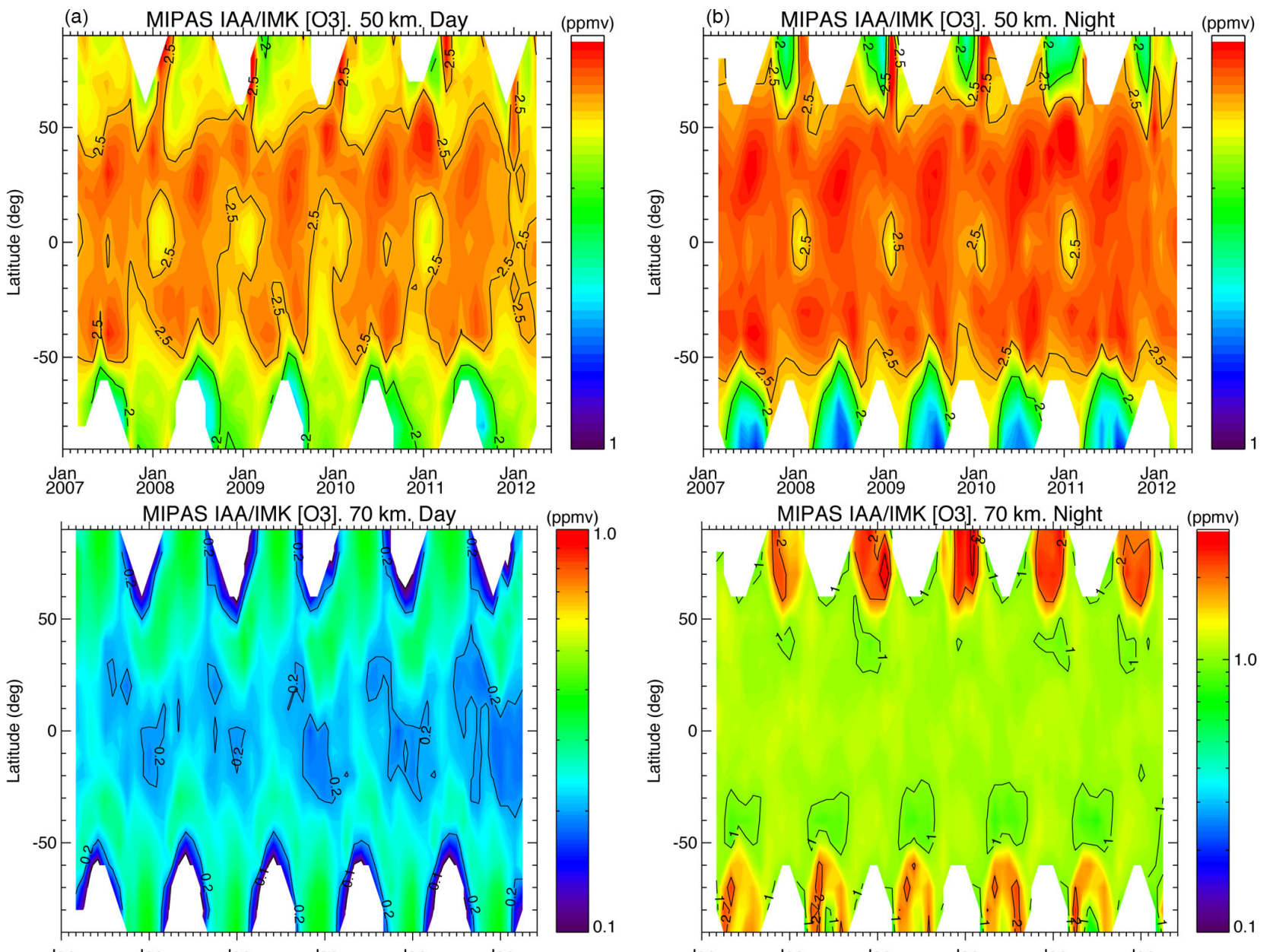

$\begin{array}{cccccc}\operatorname{Jan} & \operatorname{Jan} & \mathrm{Jan} & \mathrm{Jan} & \mathrm{Jan} & \mathrm{Jan} \\ 2007 & 2008 & 2009 & 2010 & 2011 & 2012\end{array}$
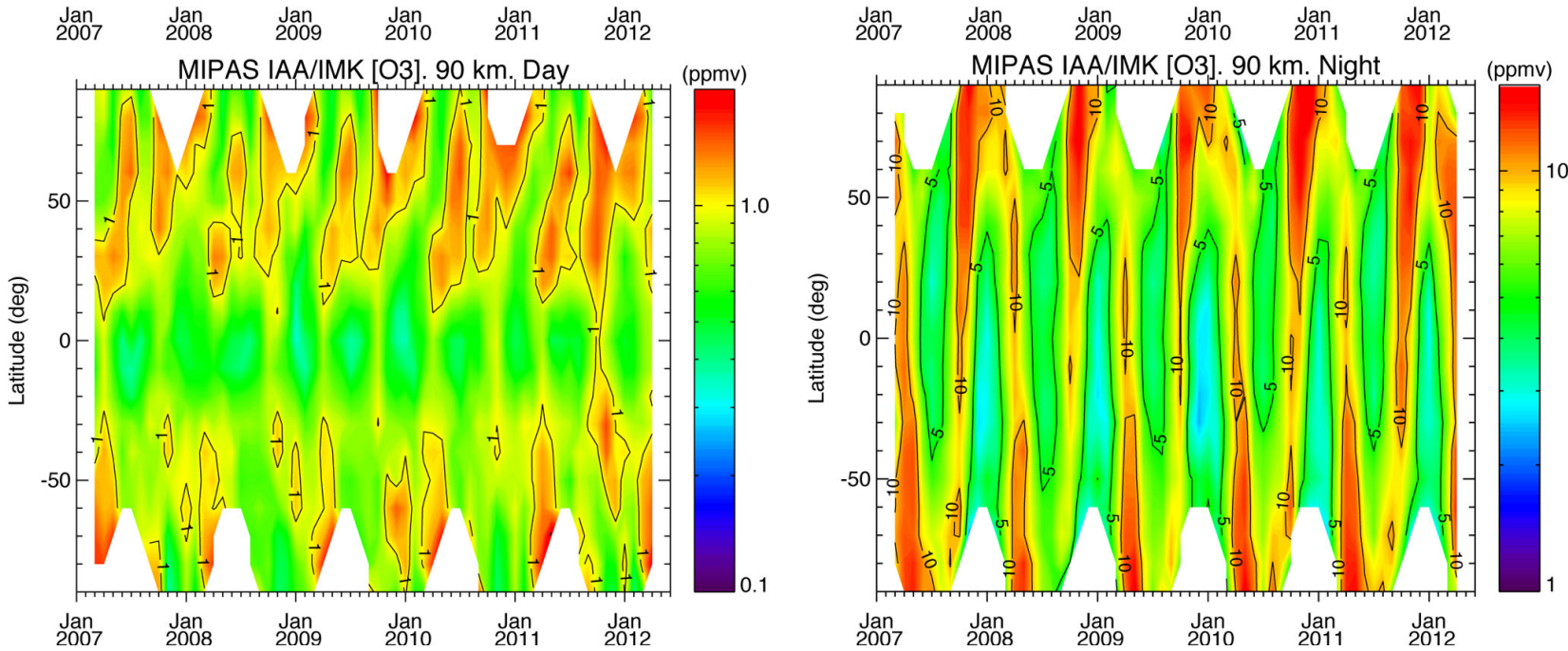

Figure 16. Cross section of latitude-time MIPAS $\mathrm{O}_{3}$ at 50, 70 and $90 \mathrm{~km}$ for daytime (a) and nighttime (b). Note the different colour scales in some panels.

slightly smaller values in daytime due to losses by photodissociation. This diurnal variation increases with altitude and at $70 \mathrm{~km}$ it is already quite large.
The presence of the tertiary maximum near $70 \mathrm{~km}$ at the polar regions leads to larger $\mathrm{O}_{3} \mathrm{VMR}$ values at these latitudes than at tropical and mid-latitudes, opposite to the latitudinal gradient shown at $50 \mathrm{~km}$. In the middle/right panel of Fig. 16 
we also observe that the nighttime tertiary maximum near $70 \mathrm{~km}$ is larger in the $\mathrm{NH}$ than in the $\mathrm{SH}$, as discussed above.

As described above, the bottom/left panel shows that the tropical daytime $\mathrm{O}_{3}$ at $90 \mathrm{~km}$ shows lowest concentrations close to the solar cycle minimum in 2009/2010. This behaviour is in concordance with model simulations (Marsh et al., 2007) and is explained by decreased odd oxygen production via $\mathrm{O}_{2}$ photolysis at low solar activity conditions. The opposite occurs, however, at $70 \mathrm{~km}$ (middle/left panel), with a tendency to decrease towards 2012. Observational evidence for a negative solar ozone response at these altitudes has been provided by the analysis of Solar Mesosphere Explorer (SME) data on solar rotation timescales (Keating et al., 1987). Our observations suggest a long-term decline rather than a solar cycle variation since no $\mathrm{O}_{3}$ increase before the solar minimum in 2009 can be identified. However, a clear attribution is not possible due to the relatively short observation period of MIPAS.

\section{Summary and conclusions}

In this paper we describe the stratospheric and mesospheric ozone distributions (version V5r_O3_m22) retrieved from MIPAS observations in the three middle atmosphere modes (MA, NLC, and UA) taken with an unapodized spectral resolution of $0.0625 \mathrm{~cm}^{-1}$ from 2005 until April 2012. The non-LTE modelling of $\mathrm{O}_{3}$ is described in detail with emphasis on the unknown atmospheric and model parameters required to retrieve ozone from limb emission measurements near $10 \mu \mathrm{m}$. In particular we discuss the role of atomic oxygen, which can be obtained during daytime by assuming it is in photochemical equilibrium with the retrieved $\mathrm{O}_{3}$, but it is a source of uncertainty at night.

We succinctly described the retrieval method and update the $\mathrm{O}_{3}$ non-LTE model parameters and the new microwindows.

Regarding the quality of the retrieved MIPAS O 3 , for daytime it has an average vertical resolution of $3-4 \mathrm{~km}$ below $70 \mathrm{~km}, 6-8 \mathrm{~km}$ at $70-80 \mathrm{~km}, 8-10 \mathrm{~km}$ at $80-90$, and $5-7 \mathrm{~km}$ at the secondary maximum $(90-100 \mathrm{~km})$. For nighttime conditions the vertical resolution is similar below $70 \mathrm{~km}$, and it is better in the upper mesosphere and lower thermosphere. It is $4-6 \mathrm{~km}$ at $70-100 \mathrm{~km}$ (except a narrow region near $80 \mathrm{~km}$ where it is coarser), 4-5 km at the secondary maximum, and $6-8 \mathrm{~km}$ at $100-105 \mathrm{~km}$. We recommend using MIPAS $\mathrm{O}_{3}$ only when the absolute value of the diagonal (or the mean diagonal when averaging) of the averaging kernel is larger than 0.03 .

The ozone noise error for daytime is typically smaller than $2 \%$ below $50 \mathrm{~km}, 2-10 \%$ between 50 and $70 \mathrm{~km}, 10-20 \%$ at $70-90 \mathrm{~km}$, and $\sim 30 \%$ above $95 \mathrm{~km}$. For nighttime, the noise errors are very similar below around $70 \mathrm{~km}$ but significantly smaller above, being $10-20 \%$ at $75-95 \mathrm{~km}, 20-30 \%$ at $95-$ $100 \mathrm{~km}$, and larger than $30 \%$ above $100 \mathrm{~km}$.
The major $\mathrm{O}_{3}$ parameter errors are the spectroscopic data uncertainties below $50 \mathrm{~km}(10-12 \%)$ and the non-LTE and temperature errors above about $70 \mathrm{~km}$. The validation analysis points to differences vs. other datasets that are well within the estimated systematic uncertainties.

The non-LTE error (including the uncertainty of atomic oxygen at night) is significant only above $\sim 85 \mathrm{~km}$ with values of $15-20 \%$. The temperature error varies from $\sim 3 \%$ near $80 \mathrm{~km}$ to $15-20 \%$ near $100 \mathrm{~km}$. Between 50 and $70 \mathrm{~km}$, the pointing and the spectroscopic errors are the dominant uncertainties.

The ozone of this version shows, compared with the previous V4O_O3_m02 version (V4O_502 in some papers), an increase of $2-3 \%(0.2-0.5 \mathrm{ppmv})$ below around $40 \mathrm{~km}$ (except in the polar winter where it is smaller), a decrease of $\sim 5-10 \%$ ( 0.4-0.5 ppmv) between 40 and $50 \mathrm{~km}$ (due to the use of MWs of channel A only), and an increase of about $2-5 \%(0.1-0.2 \mathrm{ppmv})$ at 50-80 km. In the upper mesosphere, there is a general decrease of $\sim 0.5-1$ ppmv at night, principally caused by neglecting the removal of $\mathrm{O}_{3}\left(v_{3}\right)$ by chemical reaction with atomic oxygen. Above around $95 \mathrm{~km}$, the $\mathrm{O}_{3}$ in the new version is larger in about 5-10\% due to the use of the larger atomic oxygen from the WACCM model.

The validation performed in comparisons with SABER, GOMOS, MLS, SMILES, and ACE-FTS shows that MIPAS $\mathrm{O}_{3}$ has an accuracy better than $5 \%$ at and below $50 \mathrm{~km}$, with a positive bias of a few percent. In that region, MIPAS systematic errors, mainly caused by the $\mathrm{O}_{3}$ air-broadened halfwidths of the $v_{2}$ band, seem to be overestimated. In the 50$75 \mathrm{~km}$ region MIPAS $\mathrm{O}_{3}$ has a positive bias of approximately $10 \%$, which is possibly caused in part by $\mathrm{O}_{3}$ spectroscopic errors in the $10 \mu \mathrm{m}$ region. Between 75 and $90 \mathrm{~km}$, MIPAS nighttime $\mathrm{O}_{3}$ is in agreement with other instruments by $10 \%$. In daytime, in this region, because of the low $\mathrm{O}_{3}$ values, the error can be $\sim 10-20 \%$. Above $90 \mathrm{~km}, \mathrm{MIPAS} \mathrm{O}_{3}$ in daytime is in agreement with other instruments by $10 \%$. At night, however, it shows a positive bias increasing from $10 \%$ at $90 \mathrm{~km}$ to $20 \%$ at $95-100 \mathrm{~km}$, which is attributed to the large abundances of atomic oxygen of the WACCM model.

The systematically larger $\mathrm{O}_{3}$ measured by SABER below $50 \mathrm{~km}$ when compared with all instruments considered here, including MIPAS, which in this region uses the $v_{2}$ band near $14.8 \mu \mathrm{m}$ but not the $10 \mu \mathrm{m}$ bands used by SABER, suggests that there might be a problem in the spectroscopic data of the $\mathrm{O}_{3} 10 \mu \mathrm{m}$ bands (or another unknown problem).

The global latitude coverage together with measurements at two fixed local times makes MIPAS $\mathrm{O}_{3}$ very useful for studying the seasonal changes and partially its diurnal variation, globally in both hemispheres. The major features are summarised here. The latitudinal-seasonal distribution of daytime $\mathrm{O}_{3}$ in the secondary maximum, near $90-95 \mathrm{~km}$, shows maxima near the polar winters where the SZA is rather large and losses by photodissociation smaller. Near the tropics it exhibits a minimum which is attributed to tidal effects (see e.g. Marsh et al., 2002; Dikty et al., 2010). 
MIPAS $\mathrm{O}_{3}$ data also show the typical tertiary maximum, taking place around $60-75 \mathrm{~km}$ in the winter seasons at latitudes polewards of $60-70^{\circ}$. Its extension and magnitude are larger in the middle of the winters and exhibit a hemispheric asymmetry with larger values in the NH. Furthermore, it has larger values during nighttime when it is usually shifted equatorwards. These features are in concordance with the results reported by Smith et al. (2018).

Note that $\mathrm{O}_{3}$ is higher in these regions in the late autumn to early winter (November-December in the NH and MayJune in the $\mathrm{SH}$ ), similar to the results reported by Smith et al. (2014). These investigators have shown that this $\mathrm{O}_{3}$ enhancement is caused by the relatively weak meridional circulation at those times and regions, which leads to low temperatures and low $\mathrm{H}$ concentrations, both favouring the production of $\mathrm{O}_{3}$.

The ozone nighttime secondary maximum presents the largest values in the early polar winters, decreases as the season progresses, and recovers near the end of the winter. This is in concordance with the results reported by Smith et al. (2014). Thus, during solstice, the $\mathrm{O}_{3}$ nighttime secondary maximum shows a latitudinal gradient growing from summer to winter. During equinox, the nighttime secondary maximum exhibits an apparent signature of the diurnal migrating tide, reaching the highest VMRs (up to about 20 ppmv) at the Equator near $95 \mathrm{~km}$.

MIPAS $\mathrm{O}_{3}$ upper-mesospheric data also exhibit the effects of the SAO in the tropics and mid-latitudes.

The tropical daytime $\mathrm{O}_{3}$ at $90 \mathrm{~km}$ shows the lowest concentrations close to the solar cycle minimum in 2009/2010 in concordance with model simulations (Marsh et al., 2007) and explained by decreased odd oxygen production via $\mathrm{O}_{2}$ photolysis at low solar activity conditions. At $70 \mathrm{~km}$, however, one observes an opposite effect, with a tendency for ozone decreases towards 2012.

Observational evidence for a negative solar ozone response near $70 \mathrm{~km}$ has been provided by the Solar Mesosphere Explorer (Keating et al., 1987). MIPAS data suggest, however, more of a long-term decline than a solar cycle variation, although a clear attribution is not possible due to the relatively short observation period of MIPAS.

Data availability. The MIPAS datasets used in this paper can be accessed at https://www.imk-asf.kit.edu/english/308.php (IMK-IAA MIPAS team, 2017).

Competing interests. The authors declare that they have no conflict of interest.

Acknowledgements. The IAA team was supported by the Spanish MICINN under the project ESP2014-54362-P and EC FEDER funds. The IAA and IMK teams were partially supported by
ESA $\mathrm{O}_{3}-\mathrm{CCI}$ and MesosphEO projects. Maya García-Comas was financially supported by MINECO through its "Ramón y Cajal" subprogram. Funding for the Atmospheric Chemistry Experiment comes primarily from the Canadian Space Agency. Work at the Jet Propulsion Laboratory was performed under contract with the National Aeronautics and Space Administration.

Edited by: William Ward

Reviewed by: two anonymous referees

\section{References}

Bernath, P. F.: The Atmospheric Chemistry Experiment (ACE), J. Quant. Spectrosc. Ra., 186, 3-16, https://doi.org/10.1016/j.jqsrt.2016.04.006, 2017.

Bertaux, J. L., Kyrölä, E., Fussen, D., Hauchecorne, A., Dalaudier, F., Sofieva, V., Tamminen, J., Vanhellemont, F., Fanton d'Andon, O., Barrot, G., Mangin, A., Blanot, L., Lebrun, J. C., Pérot, K., Fehr, T., Saavedra, L., Leppelmeier, G. W., and Fraisse, R.: Global ozone monitoring by occultation of stars: an overview of GOMOS measurements on ENVISAT, Atmos. Chem. Phys., 10, 12091-12148, https://doi.org/10.5194/acp-1012091-2010, 2010.

Boone, C. D., Walker, K. A.,, and Bernath, P. F.: Version 3 retrievals for the Atmospheric Chemistry Experiment Fourier Transform Spectrometer (ACE-FTS), in: The Atmospheric Chemistry Experiment ACE at 10: A Solar Occultation Anthology, edited by: Bernath, P. F., A. Deepak Publishing, Hampton, Virginia, USA, 103-127, 2013.

Brasseur, G. and Solomon, S.: Aeronomy of the Middle Atmosphere-Chemistry and Physics of the Stratosphere and Mesosphere, Atmospheric and Oceanographic Sciences Library 32, third edn., Springer, Dordrecht, the Netherlands, 2005.

Burkholder, J., Abbatt, J., Huie, R., Kolb, C. E., Orkin, V., Wine, P., Sander, S., Barker, J. R., Kurylo, M., and Wilmouth, D. M.: Chemical Kinetics and Photochemical Data for Use in Atmospheric Studies, Jet Propulsion Laboratory, Pasadena, California, USA, Evaluation Number 18, 2015.

De Laurentis, M.: Planning of MIPAS New Special Modes January 2005 Campaign, Tech. rep., ESA Technical Note, ENVISPPA-EOPG-TN-05-0002, ESA-ESRIN, Frascati, Italy, 2005.

Dikty, S., Schmidt, H., Weber, M., von Savigny, C., and Mlynczak, M. G.: Daytime ozone and temperature variations in the mesosphere: a comparison between SABER observations and HAMMONIA model, Atmos. Chem. Phys., 10, 8331-8339, https://doi.org/10.5194/acp-10-8331-2010, 2010.

Fischer, H., Birk, M., Blom, C., Carli, B., Carlotti, M., von Clarmann, T., Delbouille, L., Dudhia, A., Ehhalt, D., Endemann, M., Flaud, J. M., Gessner, R., Kleinert, A., Koopman, R., Langen, J., López-Puertas, M., Mosner, P., Nett, H., Oelhaf, H., Perron, G., Remedios, J., Ridolfi, M., Stiller, G., and Zander, R.: MIPAS: an instrument for atmospheric and climate research, Atmos. Chem. Phys., 8, 2151-2188, https://doi.org/10.5194/acp-8-2151-2008, 2008.

Funke, B., López-Puertas, M., Stiller, G. P., von Clarmann, T., and Höpfner, M.: A new non-LTE Retrieval Method for Atmospheric Parameters From MIPAS-ENVISAT Emission Spectra, Adv. Space Res., 27, 1099-1104, https://doi.org/10.1016/S02731177(01)00169-7, 2001. 
Funke, B., López-Puertas, M., García-Comas, M., Kaufmann, M., Höpfner, M., and Stiller, G. P.: GRANADA: a Generic RAdiative traNsfer AnD non-LTE population Algorithm J. Quant. Spectrosc. Ra., 113, 1771-1817, https://doi.org/10.1016/j.jqsrt.2012.05.001, 2012.

Garcia, R. R., Dunkerton, T. J., Lieberman, R. S., and Vincent, R. A.: Climatology of the semiannual oscillation of the tropical middle atmosphere, J. Geophys. Res., 102, 26019-26032, https://doi.org/10.1029/97JD00207, 1997.

Garcia, R. R., López-Puertas, M., Funke, B., Marsh, D. R., Kinnison, D. E., Smith, A. K., and González-Galindo, F.: On the distribution of $\mathrm{CO}_{2}$ and $\mathrm{CO}$ in the mesosphere and lower thermosphere, J. Geophys. Res., 119, 5700-5718, https://doi.org/10.1002/2013JD021208, 2014.

García-Comas, M., López-Puertas, M., Marshall, B., Wintersteiner, P. P., Funke, B., Bermejo-Pantaléon, D., Mertens, C. J., Remsberg, E. E., Gordley, L. L., Mlynczak, M., and Russell, J.: Errors in SABER kinetic temperature caused by non-LTE model parameters, J. Geophys. Res., 113, D24106, https://doi.org/10.1029/2008JD010105, 2008.

García-Comas, M., Funke, B., López-Puertas, M., BermejoPantaleón, D., Glatthor, N., von Clarmann, T., Stiller, G., Grabowski, U., Boone, C. D., French, W. J. R., Leblanc, T., López-González, M. J., and Schwartz, M. J.: On the quality of MIPAS kinetic temperature in the middle atmosphere, Atmos. Chem. Phys., 12, 6009-6039, https://doi.org/10.5194/acp12-6009-2012, 2012.

García-Comas, M., Funke, B., Gardini, A., López-Puertas, M., Jurado-Navarro, A., von Clarmann, T., Stiller, G., Kiefer, M., Boone, C. D., Leblanc, T., Marshall, B. T., Schwartz, M. J., and Sheese, P. E.: MIPAS temperature from the stratosphere to the lower thermosphere: Comparison of vM21 with ACE-FTS, MLS, OSIRIS, SABER, SOFIE and lidar measurements, Atmos. Meas. Tech., 7, 3633-3651, https://doi.org/10.5194/amt-7-36332014, 2014.

Gil-López, S., López-Puertas, M., Kaufmann, M., Funke, B., García-Comas, M., Koukouli, M. E., Glatthor, N., Grabowski, U., Höpfner, Stiller, G. P., and von Clarmann, T.: Retrieval of stratospheric and mesospheric $\mathrm{O}_{3}$ from high resolution MIPAS spectra at 15 and $10 \mu \mathrm{m}$, Adv. Space Res., 36, 943-951, https://doi.org/10.1016/j.asr.2005.05.123, 2005.

Glatthor, N., von Clarmann, T., Fischer, H., Funke, B., GilLópez, S., Grabowski, U., Höpfner, M., Kellmann, S., Linden, A., López-Puertas, M., Mengistu Tsidu, G., Milz, M., Steck, T., Stiller, G. P., and Wang, D.-Y.: Retrieval of stratospheric ozone profiles from MIPAS/ENVISAT limb emission spectra: a sensitivity study, Atmos. Chem. Phys., 6, 2767-2781, https://doi.org/10.5194/acp-6-2767-2006, 2006.

Gordon, I. E., Rothman, L. S., Hill, C., Kochanov, R. V., Tan, Y., Bernath, P. F., Birk, M., Boudon, V., Campargue, A., Chance, K. V., Drouin, B. J., Flaud, J. M., Gamache, R. R., Hodges, J. T., Jacquemart, D., Perevalov, V. I., Perrin, A., Shine, K. P., Smith, M. A. H., Tennyson, J., Toon, G. C., Tran, H., Tyuterev, V. G., Barbe, A., Császár, A. G., Devi, V. M., Furtenbacher, T., Harrison, J. J., Hartmann, J. M., Jolly, A., Johnson, T. J., Karman, T., Kleiner, I., Kyuberis, A. A., Loos, J., Lyulin, O. M., Massie, S. T., Mikhailenko, S. N., Moazzen-Ahmadi, N., Müller, H. S. P., Naumenko, O. V., Nikitin, A. V., Polyansky, O. L., Rey, M., Rotger, M., Sharpe, S. W., Sung, K., Starikova, E., Tashkun, S.
A., Auwera, J. V., Wagner, G., Wilzewski, J., Wcisło, P., Yu, S., and Zak, E. J.: The HITRAN2016 molecular spectroscopic database, J. Quant. Spectrosc. Ra., 203(Supplement C), 3-69, https://doi.org/10.1016/j.jqsrt.2017.06.038, 2017.

Imai, K., Fujiwara, M., Inai, Y., Manago, N., Suzuki, M., Sano, T., Mitsuda, C., Naito, Y., Hasebe, F., Koide, T., and Shiotani, M.: Comparison of ozone profiles between Superconducting Submillimeter-Wave Limb-Emission Sounder and worldwide ozonesonde measurements, J. Geophys. Res., 118, 12755 12765, https://doi.org/10.1002/2013JD021094, 2013a.

Imai, K., Manago, N., Mitsuda, C., Naito, Y., Nishimoto, E., Sakazaki, T., Fujiwara, M., Froidevaux, L., von Clarmann, T., Stiller, G. P., Murtagh, D. P., Rong, P.-p., Mlynczak, M. G., Walker, K. A., Kinnison, D. E., Akiyoshi, H., Nakamura, T., Miyasaka, T., Nishibori, T., Mizobuchi, S., Kikuchi, K.-i., Ozeki, H., Takahashi, C., Hayashi, H., Sano, T., Suzuki, M., Takayanagi, M., and Shiotani, M.: Validation of ozone data from the Superconducting Submillimeter-Wave Limb-Emission Sounder (SMILES), J. Geophys. Res., 118, 5750-5769, 2013b.

IMK-IAA MIPAS team: MIPAS/Envisat data, available at: https: //www.imk-asf.kit.edu/english/308.php, last access: December 2017.

Jurado-Navarro, Á. A., López-Puertas, M., Funke, B., GarcíaComas, M., Gardini, A., González-Galindo, F., Stiller, G. P., Clarmann, T. V., Grabowski, U., and Linden, A.: Global distributions of $\mathrm{CO}_{2}$ volume mixing ratio in the middle and upper atmosphere from daytime MIPAS high-resolution spectra, Atmos. Meas. Tech., 9, 6081-6100, https://doi.org/10.5194/amt-9-60812016, 2016.

Kaufmann, M., Gusev, O. A., Grossmann, K. U., MartínTorres, F. J., Marsh, D. R., and Kutepov, A. A.: Satellite observations of daytime and nighttime ozone in the mesosphere and lower thermosphere, J. Geophys. Res., 108, 4399, https://doi.org/10.1029/2002JD003186, 2003.

Keating, G. M., Pitts, M. C., Brasseur, G., and De Rudder, A.: Response of middle atmosphere to short-term solar ultraviolet variations: 1. Observations, J. Geophys. Res., 92, 889-902, https://doi.org/10.1029/JD092iD01p00889, 1987.

Kikuchi, K.-I., Nishibori, T., Ochiai, S., Ozeki, H., Irimajiri, Y., Kasai, Y., Koike, M., Manabe, T., Mizukoshi, K., Murayama, Y., Nagahama, T., Sano, T., Sato, R., Seta, M., Takahashi, C., Takayanagi, M., Masuko, H., Inatani, J., Suzuki, M., and Shiotani, M.: Overview and early results of the Superconducting Submillimeter-Wave LimbEmission Sounder (SMILES), J. Geophys. Res., 115, D23306, https://doi.org/10.1029/2010JD014379, 2010.

Kyrölä, E., Tamminen, J., Sofieva, V., Bertaux, J. L., Hauchecorne, A., Dalaudier, F., Fussen, D., Vanhellemont, F., Fanton d'Andon, O., Barrot, G., Guirlet, M., Fehr, T., and Saavedra de Miguel, L.: GOMOS $\mathrm{O}_{3}, \mathrm{NO}_{2}$, and $\mathrm{NO}_{3}$ observations in 2002-2008, Atmos. Chem. Phys., 10, 7723-7738, https://doi.org/10.5194/acp-10-7723-2010, 2010a.

Kyrölä, E., Tamminen, J., Sofieva, V., Bertaux, J. L., Hauchecorne, A., Dalaudier, F., Fussen, D., Vanhellemont, F., Fanton d'Andon, O., Barrot, G., Guirlet, M., Mangin, A., Blanot, L., Fehr, T., Saavedra de Miguel, L., and Fraisse, R.: Retrieval of atmospheric parameters from GOMOS data, Atmos. Chem. Phys., 10, 11881-11903, https://doi.org/10.5194/acp-1011881-2010, 2010b. 
Livesey, N. J., Read, W. G., Wagner, P. A., Froidevaux, L., Lambert, A., Manney, G. L., Millán-Valle, L. F., Pumphrey, H. C., Santee, M. L., Schwartz, M. J., Wang, S., Fuller, R. A., Jarnot, R. F., Knosp, B. W., and Martinez, E.: Version 4.2x Level 2 data quality and description document, Tech. Rep. JPL D-33509 Rev. C, Jet Propulsion Lab, Pasadena, California, USA, 2017.

López-Puertas, M. and Taylor, F. W.: Non-LTE radiative transfer in the Atmosphere, World Scientific Pub., Singapore, 2001.

Marsh, D. R., Skinner, W. R., Marshall, A. R., Hays, P. B., Ortland, D. A., and Yee, J.-H.: High Resolution Doppler Imager observations of ozone in the mesosphere and lower thermosphere, J. Geophys. Res., 107, 4390, https://doi.org/10.1029/2001JD001505, 2002.

Marsh, D. R., Garcia, R. R., Kinnison, D. E., Boville, B. A., Sassi, F., Solomon, S. C., and Matthes, K.: Modeling the whole atmosphere response to solar cycle changes in radiative and geomagnetic forcing, J. Geophys. Res., 112, D23306, https://doi.org/10.1029/2006JD008306, 2007.

Martin-Torres, F. J.: Emisiones Infrarrojas del Ozono en la Atmósfera de la Tierra, Ph.D. thesis, Univ. of Granada, Granada, Spain, 1999.

Menard, J., Doyennette, L., and Menard-Bourcin, F.: Vibrational relaxation of ozone in $\mathrm{O}_{3}-\mathrm{O}_{2}$ and $\mathrm{O}_{3}-\mathrm{N}_{2}$ gas mixtures from infrared double-resonance measurements in the $200-300 \mathrm{~K}$ temperature range, J. Chem. Phys., 96, 5773, 1992.

Mitsuda, C., Suzuki, M., Iwata, Y., Manago, N., Naito, Y., Takahashi, C., Imai, K., Nishimoto, E., Hayashi, H., Shiotani, M., Sano, T., Takayanagi, M., and Taniguchi, H.: Current status of level 2 product of Superconducting SubmillimeterWave Limb-Emission Sounder (SMILES), in: Sensors, Systems, and Next-Generation Satellites XV, edited by: Meynart, R., Neeck, S. P., and Shimoda, H., SPIE, vol. 8176, p. 6, https://doi.org/10.1117/12.898135, 2011.

Mlynczak, M. G., Hunt, L. A., Mast, J. C., Thomas Marshall, B., Russell, J. M., Smith, A. K., Siskind, D. E., Yee, J.-H., Mertens, C. J., Javier Martin-Torres, F., Earl Thompson, R., Drob, D. P., and Gordley, L. L.: Atomic oxygen in the mesosphere and lower thermosphere derived from SABER: algorithm theoretical basis and measurement uncertainty, J. Geophys. Res., 118, 5724-5735, https://doi.org/10.1002/jgrd.50401, 2013.

Moreira, L., Hocke, K., and Kämpfer, N.: Comparison of ozone profiles and influences from the tertiary ozone maximum in the night-to-day ratio above Switzerland, Atmos. Chem. Phys., 17, 10259-10268, https://doi.org/10.5194/acp-17-10259-2017, 2017.

Oelhaf, H.: MIPAS Mission Plan, ESA Technical Note ENVISPPA-EOPG-TN-07-0073, ESA-ESRIN, Frascati, Italy, 2008.

Parrish, A., Boyd, I. S., Nedoluha, G. E., Bhartia, P. K., Frith, S. M., Kramarova, N. A., Connor, B. J., Bodeker, G. E., Froidevaux, L., Shiotani, M., and Sakazaki, T.: Diurnal variations of stratospheric ozone measured by ground-based microwave remote sensing at the Mauna Loa NDACC site: measurement validation and GEOSCCM model comparison, Atmos. Chem. Phys., 14, 7255-7272, https://doi.org/10.5194/acp-14-7255-2014, 2014.

Picone, J., Hedin, A., Drob, D., and Aikin, A.: NRLMSISE00 empirical model of the atmosphere: statistical comparisons and scientific issues, J. Geophys. Res., 107, 1468, https://doi.org/10.1029/2002JA009430, 2002.
Raspollini, P., Carli, B., Ceccherini, S., Forzieri, G., Sgheri, L., Ridolfi, M., Carlotti, M., Papandrea, E., Arnone, E., Dinelli, B. M., Castelli, E., Remedios, J., Sembhi, H., Dudhia, A., LopezPuertas, M., Funke, B., Flaud, J.-M., von Clarmann, T., Hoepfner, M., Oelhaf, H., Fischer, H., Kiefer, M., Kleinert, A., Chipperfield, M., Perron, G., Aubertin, G., Birk, M., Wagner, G., Gessner, R., Mosner, P., Schmitt, M., Fehr, T., D’Alba, L., and Niro, F.: Level 2 near-real-time analysis of MIPAS measurements on ENVISAT, in: Eight Years of MIPAS Measurements, vol. SP-686, pp. 011-d2, ESA Publication Division, Noordwijk, the Netherlands, 2010.

Remsberg, E. E.: On the response of Halogen Occultation Experiment (HALOE) stratospheric ozone and temperature to the 11 year solar cycle forcing, J. Geophys. Res., 113, D22304, https://doi.org/10.1029/2008JD010189, 2008.

Rienecker, M. M., Suarez, M. J., Gelaro, R., Todling, R., Bacmeister, J., Liu, E., Bosilovich, M. G., Schubert, S. D., Takacs, L., Kim, G.-K., Bloom, S., Chen, J., Collins, D., Conaty, A., da Silva, A., Gu, W., Joiner, J., Koster, R. D., Lucchesi, R., Molod, A., Owens, T., Pawson, S., Pegion, P., Redder, C. R., Reichle, R., Robertson, F. R., Ruddick, A. G., Sienkiewicz, M., and Woollen, J.: MERRA: NASA's Modern-Era Retrospective Analysis for Research and Applications, J. Climate, 24, 3624-3648, https://doi.org/10.1175/jcli-d-11-00015.1, 2011.

Rong, P. P., Russell, J. M., Mlynczak, M. G., Remsberg, E. E., Marshall, B. T., Gordley, L. L., and López-Puertas, M.: Validation of Thermosphere Ionosphere Mesosphere Energetics and Dynamics/Sounding of the Atmosphere using Broadband Emission Radiometry (TIMED/SABER) v1.07 ozone at $9.6 \mu \mathrm{m}$ in altitude range 15-70 km, J. Geophys. Res., 114, D04306, https://doi.org/10.1029/2008JD010073, 2009.

Rothman, L. S., Gordon, I. E., Barbe, A., Benner, D. C., Bernath, P. F., Birk, M., Boudon, V., Brown, L. R., Campargue, A., Champion, J., Chance, K., Coudert, L. H., Dana, V., Devi, V. M., Fally, S., Flaud, J., Gamache, R. R., Goldman, A., Jacquemart, D., Kleiner, I., Lacome, N., Lafferty, W. J., Mandin, J., Massie, S. T., Mikhailenko, S. N., Miller, C. E., Moazzen-Ahmadi, N., Naumenko, O. V., Nikitin, A. V., Orphal, J., Perevalov, V. I., Perrin, A., Predoi-Cross, A., Rinsland, C. P., Rotger, M., Šimečková, M., Smith, M. A. H., Sung, K., Tashkun, S. A., Tennyson, J., Toth, R. A., Vandaele, A. C., and Vander Auwera, J.: The HITRAN 2008 molecular spectroscopic database, J. Quant. Spectrosc. Ra., 110, 533572, https://doi.org/10.1016/j.jqsrt.2009.02.013, 2009.

Russell, J. M., Mlynczak, M. G., Gordley, L. L., Tansock, J. J., and Esplin, R. W.: Overview of the SABER experiment and preliminary calibration results, Optical Spectroscopic Techniques and Instrumentation for Atmospheric and Space Research III, 20 October 1999, Proc. SPIE 3756, 277-288, https://doi.org/10.1117/12.366382, 1999.

Sakazaki, T., Fujiwara, M., Mitsuda, C., Imai, K., Manago, N., Naito, Y., Nakamura, T., Akiyoshi, H., Kinnison, D. E., Sano, T., Suzuki, M., and Shiotani, M.: Diurnal ozone variations in the stratosphere revealed in observations from the Superconducting Submillimeter-Wave Limb-Emission Sounder (SMILES) on board the International Space Station (ISS), J. Geophys. Res., 118, 2991-3006, 2013.

Schanz, A., Hocke, K., and Kämpfer, N.: Daily ozone cycle in the stratosphere: global, regional and seasonal behaviour modelled 
with the Whole Atmosphere Community Climate Model, Atmos. Chem. Phys., 14, 7645-7663, https://doi.org/10.5194/acp14-7645-2014, 2014.

Schwartz, M., Froidevaux, L., Livesey, N., and Read, W.: MLS/Aura Level 2 Ozone $\left(\mathrm{O}_{3}\right)$ Mixing Ratio V004, Goddard Earth Sciences Data and Information Services Center (GES DISC), https://doi.org/10.5067/AURA/MLS/DATA2017 (last access: October 2017), 2015.

Sheese, P. E., Walker, K. A., Boone, C. D., Bernath, P. F., Froidevaux, L., Funke, B., Raspollini, P., and von Clarmann, T.: ACE-FTS ozone, water vapour, nitrous oxide, nitric acid, and carbon monoxide profile comparisons with MIPAS and MLS, J. Quant. Spectrosc. Ra., 186, 63-80, https://doi.org/10.1016/j.jqsrt.2016.06.026, 2017.

Smith, A. K., Harvey, V. L., Mlynczak, M. G., Funke, B., García-Comas, M., Hervig, M., Kaufmann, M., Kyrölä, E., López-Puertas, M., McDade, I., Randall, C. E., Russell, J. M., Sheese, P. E., Shiotani, M., Skinner, W. R., Suzuki, M., and Walker, K. A.: Satellite observations of ozone in the upper mesosphere, J. Geophys. Res., 118, 1-19, https://doi.org/10.1002/jgrd.50445, 2013.

Smith, A. K., López-Puertas, M., Funke, B., García-Comas, M., Mlynczak, M. G., and Holt, L. A.: Nighttime ozone variability in the high latitude winter mesosphere, J. Geophys. Res., 119, 1-18, https://doi.org/10.1002/2014JD021987, 2014.

Smith, A. K., Espy, P. J., Lopez-Puertas, M., and Tweedy, O. V.: Spatial and temporal structure of the tertiary ozone maximum in the polar winter mesosphere, J. Geophys. Res.-Atmos., online first, https://doi.org/10.1029/2017JD028030, 2018.

Sofieva, V. F., Kyrölä, E., Verronen, P. T., Seppälä, A., Tamminen, J., Marsh, D. R., Smith, A. K., Bertaux, J.-L., Hauchecorne, A., Dalaudier, F., Fussen, D., Vanhellemont, F., Fanton d'Andon, O., Barrot, G., Guirlet, M., Fehr, T., and Saavedra, L.: Spatio-temporal observations of the tertiary ozone maximum, Atmos. Chem. Phys., 9, 4439-4445, https://doi.org/10.5194/acp-9-4439-2009, 2009.

Sofieva, V. F., Vira, J., Kyrölä, E., Tamminen, J., Kan, V., Dalaudier, F., Hauchecorne, A., Bertaux, J.-L., Fussen, D., Vanhellemont, F., Barrot, G., and Fanton d'Andon, O.: Retrievals from GOMOS stellar occultation measurements using characterization of modeling errors, Atmos. Meas. Tech., 3, 1019-1027, https://doi.org/10.5194/amt-3-1019-2010, 2010.

Sofieva, V. F., Rahpoe, N., Tamminen, J., Kyrölä, E., Kalakoski, N., Weber, M., Rozanov, A., von Savigny, C., Laeng, A., von Clarmann, T., Stiller, G., Lossow, S., Degenstein, D., Bourassa, A., Adams, C., Roth, C., Lloyd, N., Bernath, P., Hargreaves, R. J., Urban, J., Murtagh, D., Hauchecorne, A., Dalaudier, F., van Roozendael, M., Kalb, N., and Zehner, C.: Harmonized dataset of ozone profiles from satellite limb and occultation measurements, Earth Syst. Sci. Data, 5, 349-363, https://doi.org/10.5194/essd5-349-2013, 2013.

Studer, S., Hocke, K., Schanz, A., Schmidt, H., and Kämpfer, N.: A climatology of the diurnal variations in stratospheric and mesospheric ozone over Bern, Switzerland, Atmos. Chem. Phys., 14, 5905-5919, https://doi.org/10.5194/acp-14-59052014, 2014.

Takahashi, C., Ochiai, S., and Suzuki, M.: Operational retrieval algorithms for JEM/SMILES level 2 data processing system, J. Quant. Spectrosc. Ra., 111, 160-173, 2010.
Takahashi, C., Suzuki, M., Mitsuda, C., Ochiai, S., Manago, N., Hayashi, H., Iwata, Y., Imai, K., Sano, T., Takayanagi, M., and Shiotani, M.: Capability for ozone high-precision retrieval on JEM/SMILES observation, Adv. Space Res., 48, 1076-1085, 2011.

Tamminen, J., Kyrölä, E., Sofieva, V. F., Laine, M., Bertaux, J.-L., Hauchecorne, A., Dalaudier, F., Fussen, D., Vanhellemont, F., Fanton-d'Andon, O., Barrot, G., Mangin, A., Guirlet, M., Blanot, L., Fehr, T., Saavedra de Miguel, L., and Fraisse, R.: GOMOS data characterisation and error estimation, Atmos. Chem. Phys., 10, 9505-9519, https://doi.org/10.5194/acp-109505-2010, 2010.

Tikhonov, A.: On the solution of incorrectly stated problems and method of regularization, Dokl. Akad. Nauk. SSSR, 151, 501504, 1963.

von Clarmann, T. and Echle, G.: Selection of optimized microwindows for atmospheric spectroscopy, Appl. Optics, 37, 76617669, 1998.

von Clarmann, T., Glatthor, N., Grabowski, U., Höpfner, M., Kellmann, S., Kiefer, M., Linden, A., Mengistu Tsidu, G., Milz, M., Steck, T., Stiller, G. P., Wang, D. Y., Fischer, H., Funke, B., Gil-López, S., and López-Puertas, M.: Retrieval of temperature and tangent altitude pointing from limb emission spectra recorded from space by the Michelson Interferometer for Passive Atmospheric Sounding (MIPAS), J. Geophys. Res., 108, 4736, https://doi.org/10.1029/2003JD003602, 2003.

von Clarmann, T., Höpfner, M., Kellmann, S., Linden, A., Chauhan, S., Funke, B., Grabowski, U., Glatthor, N., Kiefer, M., Schieferdecker, T., Stiller, G. P., and Versick, S.: Retrieval of temperature, $\mathrm{H}_{2} \mathrm{O}, \mathrm{O}_{3}, \mathrm{HNO}_{3}, \mathrm{CH}_{4}, \mathrm{~N}_{2} \mathrm{O}, \mathrm{ClONO}_{2}$ and $\mathrm{ClO}$ from MIPAS reduced resolution nominal mode limb emission measurements, Atmos. Meas. Tech., 2, 159-175, https://doi.org/10.5194/amt-2-159-2009, 2009.

von Clarmann, T., Funke, B., López-Puertas, M., Kellmann, S., Linden, A., Stiller, G. P., Jackman, C. H., and Harvey, V. L.: The Solar Proton events in 2012 as observed by MIPAS, Geophys. Res. Lett., 40, 1-5, https://doi.org/10.1002/grl.50119, 2013.

Waters, J. W., Froidevaux, L., Harwood, R. S., Jarnot, R. F., Pickett, H. M., Read, W. G., Siegel, P. H., Cofield, R. E., Filipiak, M. J., Flower, D. A., Holden, J. R., Lau, G. K., Livesey, N. J., Manney, G. L., Pumphrey, H. C., Santee, M. L., Wu, D. L., Cuddy, D. T., Lay, R. R., Loo, M. S., Perun, V. S., Schwartz, M. J., Stek, P. C., Thurstans, R. P., Boyles, M. A., Chandra, K. M., Chavez, M. C., Chen, G.-S., Chudasama, B. V., Dodge, R., Fuller, R. A., Girard, M. A., Jiang, J. H., Jiang, Y., Knosp, B. W., Labelle, R. C., Lam, J. C., Lee, A. K., Miller, D., Oswald, J. E., Patel, N. C., Pukala, D. M., Quintero, O., Scaff, D. M., Vansnyder, W., Tope, M. C., Wagner, P. A., and Walch, M. J.: The Earth Observing System Microwave Limb Sounder (EOS MLS) on the Aura Satellite, IEEE T. Geosci. Remote, 44, 1075-1092, https://doi.org/10.1109/TGRS.2006.873771, 2006.

West, G. A., Weston Jr., R. E., and Flynn, G. W.: Deactivation of vibrationally excited ozone by $\mathrm{O}\left({ }^{3} \mathrm{P}\right)$ atoms, Chem. Phys. Lett., 42, 488-493, 1976.

West, G. A., Weston, R. E., and Flynn, G. W.: The influence of reactant vibrational excitation on the $\mathrm{O}\left({ }^{3} \mathrm{P}\right)+\mathrm{O}_{3}$ bimolecular reaction rate, Chem. Phys. Lett., 56, 429-433, 1978. 